\title{
The impact of microbes in the orchestration of plants' resistance to biotic stress: a disease management approach
}

\author{
Matthew Chekwube Enebe ${ }^{1} \cdot$ Olubukola Oluranti Babalola $^{1}$ (D)
}

Received: 3 August 2018 /Revised: 3 October 2018 / Accepted: 3 October 2018 / Published online: 12 October 2018

(C) The Author(s) 2018

\begin{abstract}
The struggle for survival is a natural and a continuous process. Microbes are struggling to survive by depending on plants for their nutrition while plants on the other hand are resisting the attack of microbes in order to survive. This interaction is a tug of war and the knowledge of microbe-plant relationship will enable farmers/agriculturists improve crop health, yield, sustain regular food supply, and minimize the use of agrochemicals such as fungicides and pesticides in the fight against plant pathogens. Although, these chemicals are capable of inhibiting pathogens, they also constitute an environmental hazard. However, certain microbes known as plant growth-promoting microbes (PGPM) aid in the sensitization and priming of the plant immune defense arsenal for it to conquer invading pathogens. PGPM perform this function by the production of elicitors such as volatile organic compounds, antimicrobials, and/or through competition. These elicitors are capable of inducing the expression of pathogenesis-related genes in plants through induced systemic resistance or acquired systemic resistance channels. This review discusses the current findings on the influence and participation of microbes in plants' resistance to biotic stress and to suggest integrative approach as a better practice in disease management and control for the achievement of sustainable environment, agriculture, and increasing food production.
\end{abstract}

Keywords Agriculture $\cdot$ Acquired systemic resistance $\cdot$ Induced systemic resistance $\cdot$ Plant immunity $\cdot$ Plant growth-promoting microbes $\cdot$ Plant pathogen

\section{Introduction}

Defense is a strategy for survival, and for any organism to survive in this interdependent environmental ecosystem, it must defend itself or experience extinction. Every creature possesses one or more defense tools and plants are no exception. To sustain its health, vitality, and existence, plants must ward off and counteract the actions of their enemies (pathogens) through many different modes including the production of secondary metabolites known as phytoalexins or phytoanticipins (Khare et al. 2017).

The survival of plants depends on their ability to defend themselves through local and systemic responses with respect to an invasion or sensing of the presence of pathogens. These

Olubukola Oluranti Babalola

Olubukola.Babalola@nwu.ac.za

1 Food Security and Safety Niche Area, Faculty of Natural and Agricultural Sciences, North-West University, Private Bag X2046, Mmabatho 2735, South Africa defense signals are triggered by microbes (Fig. 1) at the site of infection that leads to multiple protective responses against the invader and other unrelated pathogenic species (Pieterse et al. 2014). Biotic stress induces the production of oxygenderived radicals such as $\mathrm{H}_{2} \mathrm{O}_{2}$ (hydrogen peroxide), superoxide molecules, hydroxyl, and/or oxygen radicals that are the first lines of defense for a stressed plant (Nanda et al. 2010). However, certain plant hormones (salicylic acid, jasmonic acid, ethylene) and substances like hydrogen peroxide and oxygen radicals are often implicated in the initiation and control of these phytodefense activities that trigger the production of phytoalexins, callose depositions, cell wall thickening/ strengthening, metabolite production, and pathogenesisrelated protein synthesis. Together, these responses intercept and inhibit the action of the invading pathogens (Vinale et al. 2008; Singh et al. 2016; Nie et al. 2017). These defense proteins (enzymes) are remarkable in the protection of the plant via the reaction processes they catalyze. The biosynthesis of phytoalexins and/or phenolic compounds as well as salicylic acid production is catalyzed by phenylalanine ammonia lyase. Polyphenol oxidase facilitates the redox reaction that converts 


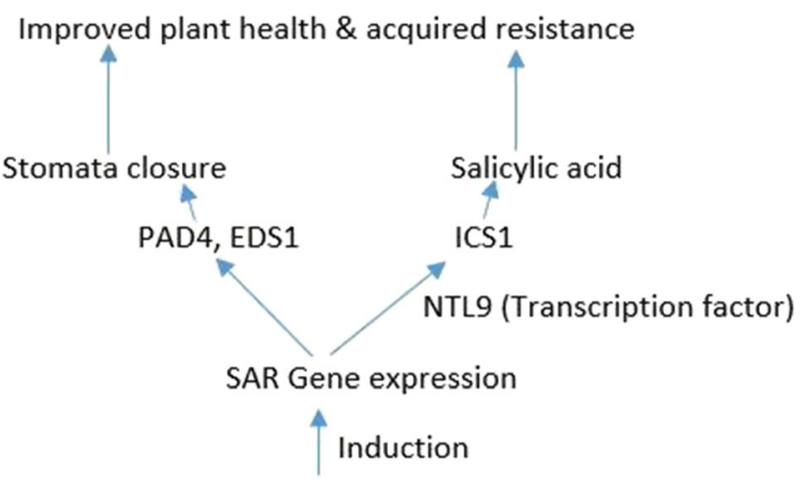

Plants response

(Production of azelaic acid, abscisic acid etc.)

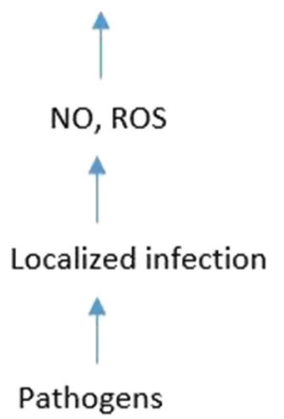

Fig. 1 The impact of pathogen infection in the acquisition of systemic resistance in plant. $P A D 4$ phytoalexin deficient $4, E D S 1$ enhanced disease susceptibility 1, ICS1 isochorismate synthase 1, NTL9 NTM1-LIKE9 transcriptional factor, $N O$ nitric oxide, $R O S$ reactive oxygen specie

polyphenol to quinone antimicrobial compounds (Gong et al. 2017). However, in the absence of biocontrol microbes, pestor pathogen-challenged plants could produce in excess of phenylalanine ammonia lyase (PAL) (Fukasawa-Akada et al. 1996; Vanitha et al. 2009), beta 1,3-glucanase, chitinase (Mauch et al. 1988), peroxidase (Van Lelyveld and Brodrick 1975), superoxide dismutase (Lu et al. 2017), and peroxidase biomolecules (Hammerschmidt et al. 1982). Pathogeninfected plants produce many compounds including alkaloids, phenolics, glucosinolates, betanins, terpenoids, cyanogenic glucosides, etc. These compounds are produced by infected cells and surrounding tissues during and after the infection. These substances can prevent pathogens from further infection of the plant (Srikantaramas et al. 2008). These defense mechanisms could best be described as an intrinsic resistant strategy by plants to biotic stress.

In the presence of beneficial microbes, pathogen-stressed plants undergo a partial or complete reprogramming of their metabolic pathways involved in the defense signaling processes to activate appropriate pathogenesis-related pathways (Singh et al. 2016). These defense mechanisms are metabolically costly to the plant. The semi-intrinsic part of the plant defense process involves reprogramming of the defensive response in plants as engineered by the rhizosphere soil microbiome. These microbiome populations are attracted by plants. Plants play a central role in the selection, initiation, and recruitment of potential microbes that will form its rhizosphere microbiome through the type and nature of exudates it releases into the rhizosphere (Spence et al. 2014; Berendsen et al. 2012). These recruited microbes include some that are beneficial and others that are antagonistic, will interact with the plant receptors, and prime their immunity. The defense immune priming in plants is initiated once the microbial extracellular structures and molecules such as exopolysaccharide, proteins, flagellins, etc., come in contact with the cell receptors on the surfaces of plant. Also, local infection of plants by pathogens as well as herbivore attack will result in a structural and functional damage of the affected part. This disruption in the structural and functional network perhaps will initiate a signal transduction from the local site of attack to other parts of the plant for proper immune sensitization. This process is mediated by the amino acid glutamate. Glutamate receptor-like family bearing charged groups and ions will pick up these signals associated with tissue damage and hence induce the accumulation of calcium ions within the plant cells. The accumulated ions will relay the impulse to distant organs responsible for the activation of the defense response genes. Therefore, glutamate triggers long-distance, calcium-based plant defense signaling (Toyota et al. 2018). In other words, this initiates the activation of a cascade of defense genes to produce reactive oxygen molecules, superoxide dismutase, peroxidase, and a host of other biomolecules (Luiz et al. 2015). These chemical substances work both within and outside plants to bring forth desired inhibitory effects on the pathogen. Priming of defense genes in plants as a result of inducers (microbes) or elicitors is termed induced systemic resistance (Stangarlin et al. 2011).

Beneficial nonpathogenic microbes interact directly with the pathogens by secreting chemical metabolites that will suppress their growth and/or render them avirulent, thereby protecting the host plant (Dey et al. 2014). This mechanism is a direct plant pathogen-assisted control by rhizomicrobes. A grampositive microbe Micromonospora obtained from the root nodules of legumes has exhibited a direct biocontrol by inhibiting the growth of many fungal pathogens. This microbe also induces jasmonic acid signaling defense in tomato plants exposed to the fungus Botrytis cinerea (Martinez-Hidalgo et al. 2015).

Over the years, the use of agrochemicals (fungicides and pesticides) to control pathogens of crops has been found to constitute an environmental hazard and causes bioaccumulation of toxic substances in the food chain. This necessitates the need for adoption of an eco-friendly alternative in solving the problem and in sustaining the environment. The use of plant growth promoting microbes has been shown to be a good option in the fight against pathogen invasion of crops (Ashwin et al. 2017; Bohm et al. 2014). With the need to boost yield and health of crops and to minimize the involvement of agrochemicals in crop disease management, identification of viable biocontrol agents as well as uncovering mechanisms 
and mediators of plants' resistance to biotic stress (as seen in the glutamate-induced long-distance defense signaling above) is paramount.

\section{Microbial induction of systemic resistance in plant to biotic stress}

The production of chemical substances and their transportation through protein channels to the site of infection and to other parts of the plant (Khare et al. 2017) undergoing a stressful condition is a direct approach to the sustenance of plant's health and vitality. The plant Arabidopsis thaliana possess high numbers of transport proteins (ABCG34) and has the ability to resist invasion of the fungus (Alternaria brassicicola) by producing and transporting the fungicidal substance camelexin to the surface of the plant leaves. The presence of this fungus stimulated the production of metabolites as well as the expression of genes (AtABCG34) responsible for the production of the transport protein (Khare et al. 2017). Nicotiana tabacum producing sclareol (diterpene alcohol) enhances the plant defenses against invading pathogens (Crouzet et al., 2013).

The biosynthesis/production of jasmonic acid within plants as a result of physiological defense impact-response of plants to pathogen invasion/attack contributes to the growth of the plant and also inhibits pathogenic infection reoccurrence. Jasmonate-induced oxygenase inactivates the jasmonic acid activity by hydroxylation reaction to bring its activities to normal as seen in Arabidopsis. An Arabidopsis mutant possessing a dysfunctional gene responsible for production of the oxygenase enzyme produced an overproduction of jasmonic acid that resulted in the inhibition of plant growth but increased the plant resistance to invasive pathogens (Caarls et al. 2017). In the presence of pathogens, salicylic acid is produced through the transcription and induction of the major synthetic gene known as isochorismate synthase 1 which is activated by the transcriptional factors (NTM1 LIKE 9 and CCA1 HIKING EXPEDITION). As seen in the induction of acquired immunity in plants, salicylic acid not only serves as a hormone but is also responsible for local and systemic resistance of plants to pathogens. It facilitates the production of plant proteins that are microbiocidal in nature. It is involved in the stomatal regulation/behavior in the presence of pathogenic microbes on the phylloplane and enhances efficient closure of this pathway against the entrance of the pathogen into the plant tissue. To perform this regulatory role, plants engage their surface receptors (flagellin sensing 2) that sense the presence of microbe-associated proteins such as flagellin which triggers the closure of the stomata and prevents the entrance of the pathogen into the plant (Zheng et al. 2015; Zeng and He 2010).

The rhizobacteria flora native to the soil has significantly reduced the incidence of disease and death of tobacco
(Nicotiana attenuata) inflicted by Fusarium or Alternaria compared to plants infected growing in a fungi-infested agricultural soil (Santhanam et al. 2015).

The application of exopolysaccharides produced by Lactobacillus plantarium on tomato plant elicited/induced the expression of defensive genes as observed with increased expression of the intracellular defense enzymes: catalase (CAT), polyphenoloxidase (PPO), superoxide dismutase (SOD), and hydrogen peroxide $\left(\mathrm{H}_{2} \mathrm{O}_{2}\right)$. These substances (Fig. 2) enhanced plant resistance to the destructive pathogen Xanthomonas gardneri, the agent that causes bacterial spot disease on tomato leaves. Exopolysaccharide treatment influenced the lowering of water movement and escape from the leaves' stomata pores by $36 \%$ (Blainski et al. 2018). Also, a protein molecule (Colletotrichum falcatum plant defenseinducing protein 1) produced by the fungus $C$. falcatum (a pathogen of sugar cane) was able to prime the expression of the defense machinery of sugar cane. This induction of the defense genes lead to the inhibition of the fungus-associated cellular lesion on the treated sugar cane plant that was challenged with the pathogen $C$. falcatum. Noticed also was stimulation of the plant's production of hydrogen peroxide and deposition of callose on the affected plant parts (Ashwin et al. 2018).

A tomato rhizosphere associated bacteria-Pseudomonas sp. - capable of producing the antimicrobial substance phenazine enhanced the intrinsic resistance of the tomato root and shoot to the attack of pathogens. It stimulated the intracellular accumulation of organic compounds (phenolics, lipoxygenase, and jasmonic acid) in the treated plant and provided protection against a wide range of pathogenic microbes (fungi, bacteria, and/or viruses) (Hariprasad et al. 2013). The gene products responsible for the control of pathogenesisrelated genes has shown that Lox3-4, ZmLox3 (lipoxygenase gene), negatively control the expression of genes capable of promoting systemic resistance in plant. But the disruption of this gene will generate a Lox3-4 mutant in maize plant. This significantly increased the leaves' systemic resistance to the pathogen Colletotrichum graminicola. In the absence of this negative control gene, the pathogenesis genes were constitutively expressed to sustain the resistance of the plant to pathogens (Constantino et al. 2013).

In the same vein, soybean treated with the bacterium Bacillus sp. CHEP5 remarkably stimulated the intrinsic resistance of the plant to the fungus Cercospora sojina Hara, an agent that causes frogeye leaf spot (FLS) disease in soybean plants. It equally empowered the plant to express defense genes responsible for jasmonic acid synthesis (Tonelli and Fabra 2014). Although bacteria involvement in induction of systemic resistance has been known, the issue is on whether this is scalable and feasible for a field crop disease control, with respect to the dynamic climate condition and varying agricultural practices and soil management. Mycorrhizal fungi 
Fig. 2 The interrelatedness of beneficial microbes, chemical inducers, and elicitors in the induction of systemic resistance in plants. EFR3 ethylene response factor, $O P R 3$ jasmonic acid signaling gene, $P R 1$ pathogenesis-related protein, $P R 2$ beta 1,3 - glucanase

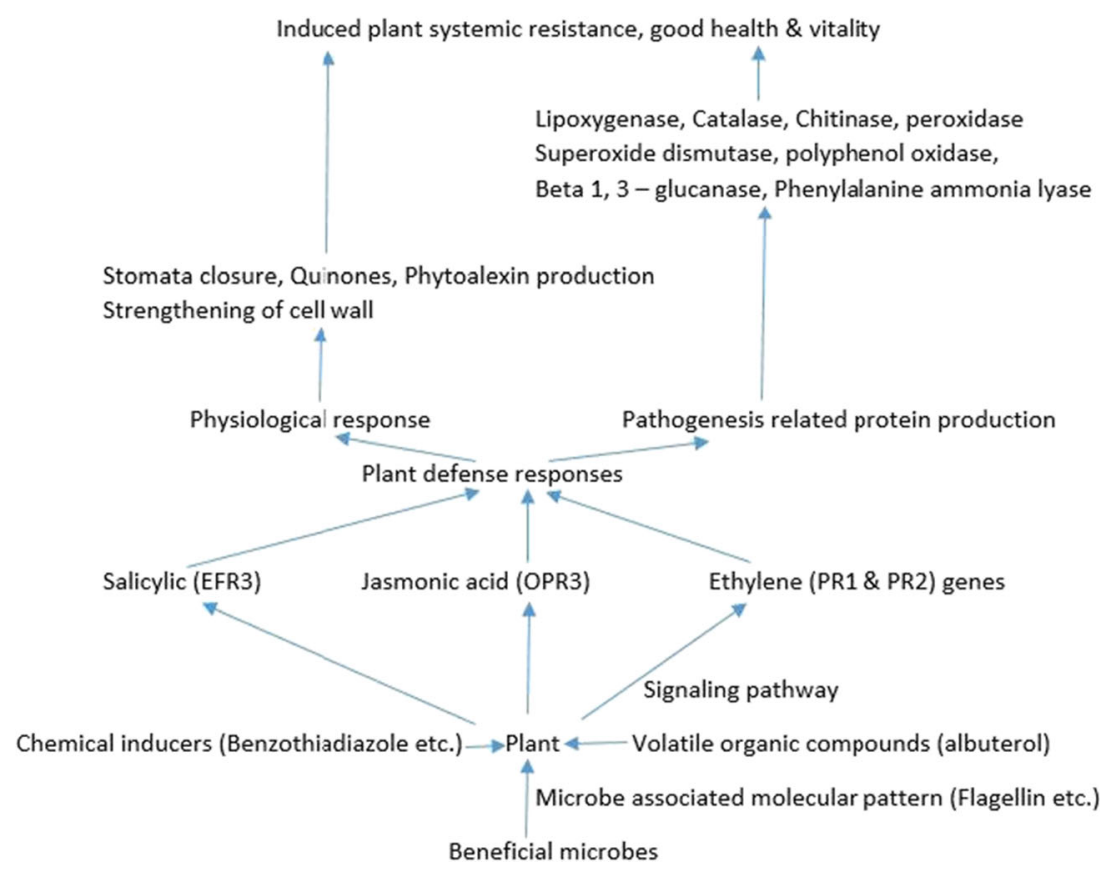

are equally implicated in the priming process of plant protective genes. They do this by root colonization and through the signaling pathway, prime jasmonic and salicylic acid synthetic genes (OPR3 and PR1). These primed genes will then boost tomato resistance (for instance) to Alternaria alternata infection. Also primed were the genes involved in the biosynthesis of enzymes such as lipoxygenase (LOX) and phenyl ammonia lyase (PAL) (Nair et al. 2014).

From a different perspective, bacterial involvement in systemic resistance of barley plants could proceed through an indirect priming of the non-expressor pathogenesis-related genes by activating the transcriptional factors (WRKY and ethylene responsive factor) which then resulted in transcriptional reprogramming of the plant for effective induction of the expression of pathogenesis-related genes. Also, exogenous application of salicylic acid (Table 1) could play a major role in plant immunity, as well as jasmonic acid methyl ester and/or abscisic acid which induce the systemic resistance of plant to Xanthomonas translucens pathovar cerecilis infection (Dey et al. 2014). Among the myriad of microbes found at the rhizosphere of maize plant, Pseudomonas putida KT2440 is an excellent root-associated bacterium and could tolerate the toxicity of maize root exudates that are inhibitory to other microbes. The mutual affinity between maize and pseudomonas enabled the bacterial presence to trigger the expression of jasmonic and abscisic acid production in the early phase of the plant relationship with the bacteria. This relationship manifested in the suppression of the gene expression of salicylic acid. However, the plant response to the bacteria presence gradually fades away as the plant begins to adjust and accommodate the presence of the associative partner. This microbe equally induced systemic resistance of maize to the infection of the fungus Colletotrichum graminicola which causes leaf necrosis (Planchamp et al. 2015). To achieve this immune enhancement of plants by microbial influence, effective communication is a prerequisite.

This communication is mediated by exchange of signaling molecules or proteins at the rhizosphere (Babalola 2014). Trichoderma virens have been found to excrete small, secreted cysteine proteins (SSCPs) which enhance the symbiosis between the microbe and the plant. These molecules perform a positive effector role in the sustenance of plant's defense to parasites as well as pathogens and in promoting the establishment of a symbiotic relationship between the plant and fungi. They are equally involved in the control of induced systemic resistance of plant by Trichoderma virens. These beneficial rhizosphere interactions empower the plant to tolerate and/or resist pathogen infection such as resistance of maize to Cochliobolus heterostrophus (Lamdan et al. 2015).

Co-inoculation of plant growth promoting rhizobacteria (Pseudomonas sp. R41805) with mycorrhizal fungi (Rhizophagus irregularis MUCL 41833) stimulated the activation of systemic defense genes of the potato plant against Rhizoctonia solani infection through the priming of the ethylene resistance network. This is an indirect approach to biocontrol of plant pathogens (Velivelli et al. 2015). In a direct biocontrol, Pseudomonas fluorescens LBUM223 possessing the intrinsic ability to produce Phenazine -1 - carboxylic acid was found to control Streptomyces sp. involvement in the infection of potato by negatively regulating the gene ( $t x t A)$ expression of the Streptomyces. This virulence and pathogenicity gene in Streptomyces responsible for thaxtomic production is involved in scab disease development in potato (Arseneault et al. 2015). The influence of root-associated 
Table 1 Microbial elicitors that induce systemic resistance in plants

\begin{tabular}{|c|c|c|c|c|}
\hline Microbes & Organic substance produced & Phytopathogens & Plants & References \\
\hline $\begin{array}{l}\text { Bacillus subtilis } 985 \text {, Bacillus } \\
\text { amyloliquefaciens } 5499\end{array}$ & Surfactin & Botrytis cinerea & Tobacco & Cawoy et al. (2014) \\
\hline Escherichia coli (recombinant) & PevD1 protein & Verticillium dahliae & Cotton & Bu et al. (2014) \\
\hline Cladosporium sp., Ampelomyces sp. & m-Cresol methyl benzoate & $\begin{array}{l}\text { Pseudomonas syringae } \\
\text { (pv. tomato DC } 3000)\end{array}$ & Arabidopsis thaliana & Naznin et al. (2014) \\
\hline Bacillus subtilis & Culture supernatant & Meloidogyne incognita & Tomato & Adam et al. (2014) \\
\hline $\begin{array}{l}\text { Phytophthora parasitica OPEL } \\
\text { protein from Recombinant } E \text {. coli }\end{array}$ & OPEL protein & $\begin{array}{l}\text { Tobacco mosaic virus, } \\
\text { Ralstonia solanacearum, } \\
\text { Phytophthora parasitica }\end{array}$ & $\begin{array}{l}\text { Nicotiana tabacum } \\
\quad(\text { cv. Samsun NN) }\end{array}$ & Chang et al. (2014) \\
\hline Bacillus subtilis & Surfactin, mycosubtilin & Botrytis cinerea & Grapevine & Farace et al. (2014) \\
\hline $\begin{array}{l}\text { Pseudomonas fluorescens RRLJ134, } \\
\text { Pseudomonas aeruginosa RRLJ04 }\end{array}$ & Phenazine analogues & $\begin{array}{l}\text { Fomes lamoensis, Ustulina } \\
\quad \text { zonata }\end{array}$ & Tea & Mishra et al. (2014) \\
\hline $\begin{array}{l}\text { Trichoderma virens, } \\
\quad \text { Trichoderma atroviride }\end{array}$ & $\begin{array}{l}\text { SM1 (small protein1) and } \\
\text { EP11 proteins (eliciting } \\
\text { plant response-like protein) }\end{array}$ & $\begin{array}{l}\text { Alternaria solani, Botrytis } \\
\text { cinerea, Pseudomonas } \\
\text { syringae pv. tomato } \\
\text { (Pst DC3000) }\end{array}$ & Tomato & $\begin{array}{l}\text { Salas-Marina et al. } \\
\text { (2015) }\end{array}$ \\
\hline Bacillus sp. SJ & Volatile compounds & $\begin{array}{l}\text { Rhizoctonia solani, } \\
\quad \text { Phytophthora nicotianae }\end{array}$ & Tobacco & Kim et al. (2015) \\
\hline Bacillus fortis IAGS 162 & Phenylacetic acid & $\begin{array}{l}\text { Fusarium oxysporum } \\
\text { f.sp. lycopersici }\end{array}$ & Tomato & Akram et al. (2016) \\
\hline Bacillus subtilis DZSY21 & Lipopeptides & Bipolaris maydis & Maize & Ding et al. (2017) \\
\hline Pseudomonas aeruginosa PM12 & $\begin{array}{l}\text { 3-Hydroxy-5-methoxy } \\
\text { benzene methanol (HMB) }\end{array}$ & Fusarium oxysporum & Tomato & $\begin{array}{l}\text { Fatima and Anjum } \\
\text { (2017) }\end{array}$ \\
\hline Bacillus subtilis SYST2 & Albuterol, 1,3-propanediol & Ralstonia solanacearum TBBS1 & Tobacco & Tahir et al. (2017) \\
\hline Pseudomonas protegens CHAO & Orfamide A & Cochlibolus miyabeanus & Rice & Ma et al. (2017) \\
\hline $\begin{array}{l}\text { Bacillus amyloliquefaciens } \\
\text { (UCMB5113) }\end{array}$ & Fengycins & Alternaria brassicicola & Arabidopsis thaliana & Asari et al. (2017) \\
\hline $\begin{array}{l}\text { Saccharothrix yanglingensis } \\
\text { (Hhs.015) }\end{array}$ & BAR11 protein & $\begin{array}{l}\text { Pseudomonas syringae pv. } \\
\text { tomato DC } 3000\end{array}$ & Arabidopsis thaliana & Zhang et al. (2018) \\
\hline $\begin{array}{l}\text { Bacillus amyloliquefaciens, } \\
\text { Bacillus subtilis }\end{array}$ & $\begin{array}{l}\text { Iturin A, Fengycin, } \\
\text { Bacillomycin }\end{array}$ & Fusarium moniliforme & Maize & Gond et al. (2015) \\
\hline
\end{tabular}

Pseudomonas fluorescens PTA-CT2 was felt in grapevine both local and systemic, as the bacteria induce systemic resistance of the plant to the pathogen $B$. cinerea. This point source as well as systemic (in roots and leaves) influence could be attributed to the transfer of metabolites from the root to the upper chamber of the plant. It also induced the expression of phytoalexin and glutathione 3-transferase with a marked decrease in the expression of hypersensitive related genes. Cell death was equally observed in the plant roots (Gruau et al. 2015). Indeed, Phytophthora cactorum, pathogen of the Korean ginseng plant that caused the dreaded root disease, was efficiently controlled by a plant growth promoting rhizobacteria (Bacillus amyloliquefaciens strain HK34) which induced systemic resistance in ginseng plant via inducing the expression of pathogenesis-related genes in the treated plant (Lee et al. 2015).

The immune response of plants to microbes could either follow one of the two main routes: SAR — systemic acquired resistance and/or ISR - induced systemic resistance. These two routes will arrive at the same point of boosting the plant immunity. Induced systemic resistance involves the activation of the plant immunity by plant interaction with beneficial nonpathogenic microbes such as the plant growth-promoting rhizomicrobes. These microbes stimulate the activation of plant immunity via its contact with the plant receptor responsible for sensing the microbe-associated molecular pattern of the microbe (Zamioudis and Pieterse 2012; Pieterse et al. 2012). Moreover, the mechanisms and signaling processes involved in microbial induction of systemic resistance have been well reviewed by Shine et al. 2018 .

The two main signaling pathways (salicylic acid and jasmonic acid/ethylene) were primed simultaneously by Bacillus cereus AR156 in A. thaliana plant. The activation of these pathways/defense genes gives rise to improved plant immunity and resistance to pathogenic microbial infection. These genes are found to be controlled by two transcriptional factors (WRKY11 and WRKY70). The presence of B. cereus has a positive stimulatory effect on the activity of WRKY70 but negatively suppresses WRKY11 in the plant. Nevertheless, transcriptional factors enable proper transcription of DNA and contribute greatly in the process of $B$. cereus induction of systemic resistance in plant. And the microorganism equally has the 
tendency to activate both salicylic acid and jasmonic acid signaling pathways simultaneously in the green vegetative plant (Jiang et al. 2015).

In line with the forgoing, mycorrhizal fungi a beneficial symbiotic microbe facilitated the induction of systemic resistance in tomato plant. This fungus on its own does not induce the priming of the pathogenesis-related genes but only do so in the presence of a pathogen. The arbuscular mycorrhizal fungus (Funneliformis mosseae) facilitated tomato resistance to Alternaria solani sorauer infection. The organism lead to an increase in beta 1,3-glucanase, chitinase, PAL, and Lox in the tomato leaves when inoculated with the microbial pathogen. Therefore, in the presence of a pathogen, arbuscular mycorrhizal fungi pre-inoculated-tomato plants have the highest defensive gene response involved in pathogenesis (namely PR1-pathogenesis-related protein, PR2-beta 1,3glucanase, and PR3 - chitinase) and defense-related genes (Lox, allene oxide cyclase (AOC), PAL) in the leaves of the tomato plant (Song et al. 2015).

A nonpathogenic bacteria, Rhizobium radiobacter, a close cousin of Agrobacterium tumifaciens (now called $R$. radiobacter biovar 1 strain C58), has the ability to activate/induce the expression of plant defense genes and boost plant immunity through jasmonic acid signaling pathway induction. This was observed in Arabidopsis challenged with the microbe Pseudomonas syringae (pv. tomato DC3000). Obviously, similar effects were observed in wheat plants challenged with Xanthomonas translucens (pv. Translucens) (xtt) (Glaeser et al. 2016). The contributions of beneficial microbes in food production through the induction of systemic resistance of plants to pathogens cannot be overemphasized. This is clearly observed in the influence of B. cereus $\mathrm{C} 1 \mathrm{~L}$ to increase the vegetative growth of maize plant and improve its resistance/tolerance to pathogenic fungalinduced disease condition (southern leaf blight that is caused by Cochliobolus heterostrophus). This alternative and ecofriendly approach to biocontrol and promotion of plant immunity through the application of a microorganism that primes plant defensive genes has a significant substituting effect to farmers' dependence on fungicides (Dithiocarbamate and mancozeb) in the control of fungi infection of plants. Unfortunately, these fungicides are capable of causing neurological disease/disorder in human beings (Parkinson's) and necessitate the use of eco-friendly microbes as a substitute (Lai et al. 2016; Ferraz et al. 1988; Meco et al. 1994).

A look at induced systemic resistance from another dimension suggested that yeast (Pseudozyma churashimaensis strain RGJ1) isolated from a pepper leaf surface exerted a protective role on the plant against the viral infections caused by the cucumber mosaic virus (CMV), pepper mottle virus (PMV), pepper mild mottle virus (PMMV), and broad bean wilt virus (BBWV) and against the bacterial pathogen Xanthomonas axonopodis. The yeast was able to boost plant immunity through the induction of plant pathogenesis-related genes involved in the salicylic/jasmonic acid signaling pathway (CaPR4) and ethylene (CaPR5) signaling pathway (Lee et al. 2017). Whenever microbes succeed in infecting a plant, the cellular level of hydrogen peroxide will increase as well as the deposition of callose in the affected plant part as a first line of defense response by the plant (Nie et al. 2017). However, treatment of $A$. thaliana with $B$. cereus (AR156) promoted the plant immunity against $B$. cinerea. The protection involved many phases of induced systemic responses that encompass the expression of protein (PR1), $\mathrm{H}_{2} \mathrm{O}_{2}$, and deposition of callose. These physiological activities were observed more in Arabidopsis pretreated with $B$. cereus and later challenged with the $B$. cinerea pathogen. Induced resistance is as a result of the activation of the jasmonic acid/ethylene dependent signaling pathway and NPR1 (non-expressor of PR1) signaling pathway (Nie et al. 2017).

Synergy is often the best approach to achieving excellent results in any biological system. The co-inoculation of Bacillus sp. (CHEP5) and Bradyrhizobium japonicum (E109) enhanced the induction of soybean resistance to C. sojina infection. This agent causes frog leaf spot disease in soybean plant. The inductive capacity of these microbes could be ascribed to their ability to form a biofilm when grown together as well as priming of the plant defense immune system (Tonelli et al. 2017).

The microbial approach to pathogen infestation control through induction of systemic resistance in plants can be perpetuated by antagonistic microbe (Pseudomonas sp. S2 and S4) not only enhanced plant growth but also reduced and controlled the epiphyte microbe Salmonella enterica, the agent of food crop associated salmonellosis in tomato, spinach, and lettuce. Inoculation of this microbe on the root of vegetable had an indirect biocontrol effect on the phylloplane microbial pathogen through the induction of systemic resistance in the inoculated plant (Hsu and Micallef 2017). The effect of Burkholderia phytofirmans (PsJN), a plant useful endophyte, was observed in the suppression of the pathogen P. syringae (pv. tomato DC3000) against its infection on A. thaliana. The presence of this microbe (B. phytofirmans) on the roots of Arabidopsis caused the expression of the salicylic acid defense gene (PR1) and the expression of PDF1.2 (a jasmonic acid and ethylene regulated gene) which fortified the immune strength of the plant against infection $(\mathrm{Su}$ et al. 2017a). A similar event was noticed in a cucumber plant pretreated with the fungus Trichoderma atroviride (TRS25) which induced resistance in the plant against $R$. solani infection. The pretreatment exercise that resulted in Rhizoctonia inhibition was a result of increased treatment activation of plant defense enzymes-guaiacol peroxidase (GPX), syringaldazine peroxidase (SPX), phenylalanine ammonia lyase (PAL), and polyphenol oxidase (PPO). Also increased was the concentration of intracellular phenolic compound, 
hydrogen peroxide, and a corresponding decrease in thiobarbituric acid concentration. The fungus equally promoted the accumulation of derivatives of salicylic acid - methyl salicylate (MeSA), ethylhexyl salicylate (EHS), salicylic acid glucosylated conjugates (SAGC), beta cyclocitral, and volatile organic compound (VOC) - 2,3 hexanal, 2,3-hexenol, and E-2-hexenal. These compounds particularly the volatile organic compound contributed greatly in the fungal induction of salicylic acid defense genes (PR1 and PR5) involved in the plant's systemic acquired resistance (Nawrocka et al. 2018).

The influence of the BjNPR1 protein was found to contribute significantly to the Brassica juncea resistance to Alternaria brassicae and Erysiphe cruciferarum infection in a transgenic Brassica plant overexpressing the BjNPR1 gene (Ali et al., 2017). The bacterium Bacillus sp. capable of inducing the production of antioxidant defense enzymes (superoxide dismutase, peroxidase, polyphenol oxidase, phenylalanine ammonia lyase) in rice plant strengthened its resistance to Pyricularia oryzae infection (Rais et al. 2017).

Although beneficial microbes are inducing systemic resistance in plants against microbial infection, yet the struggle for dominance and survival allows some pathogens to constantly devise a means to avert the inhibitory effect of plant immune components. These microbes end up producing HC-toxin (a histone deacetylase inhibitor) which reprogram the transcriptional response of plant to microbial infection and succeed in making the plants' immune defenses ineffective. This HCtoxin is produced by the pathogen (Cochliobolus carbonum race 1). The toxic substance increased the virulence and infection capacity of the microbe and also changed the acetylation of proteins in maize plant (Walley et al. 2018). The big problem is what are the chances that this HC-toxin gene will not be transferred to other microbes that are beneficial to plant? If this toxin-producing gene were to be transferred either horizontally or vertically, this will render the farmers' effort in crop production futile. For this reason, more studies should be channeled toward the identification of potential biocontrol agents that can antagonize $C$. carbonum without picking up the toxin gene from it. At present, there is very little work done in this area to help solve the problem. A good strategy will always involve cooperation and/or division of labor. Coinoculation of peanut (groundnut) plants with Bacillus sp. (CHEP5 specie) and Bradyrhizobium sp. (SEMIA6144 specie) remarkably protected the plants from the attack of the Sclerotium rolfsii (the agent that cause plant stem wilt disease) and increased the plant immunity together with the yield of the treated plant (Figueredo et al. 2017). Also, Bacillus pumilus and Paenibacillus sp. are able to secret volatile compounds (2,5 dimethyl pyrazine and 1-octen-3-ol) inhibited the proliferation of the fungus (Phaeomoniella chlamydospora, the agent that causes grapevine trunk disease). These microbes induced the expression/activation of the pathogenesis-related genes and callose synthase-genes in the plant. Therefore, production of antimicrobial/antagonistic substances take priority in the control of fungus which is followed by induction and/or priming of systemic resistance in the plant (Haidar et al. 2016).

\section{The dual role of an effective microbe}

An effective microbe has a dual role-disease control and promotion of plant growth. This attribute is found with Rhodopseudomonas palustris GJ-22. These photosynthetic bacteria not only promote Nicotiana benthamiana (tobacco) growth by producing indole acetic acid and 5 -aminolevulinic acid but also improved the plants' resistance against tobacco mosaic viral infection through priming of pathogenesisrelated genes (Su et al. 2017b). The dual role of the bacterium Azospirillum sp. B510 enable tomato plant to grow and be protected against infection by $P$. syringae (pv. Tomato) as well as $B$. cinerea which causes leaf spot and gray mold in the plant. Azospirillum enhances the immunity of the treated plant in a non-acquired systemic resistance manner (Fujita et al. 2017).

The question is can the use of these microbes be effective in the field? Is it scalable? If it is scalable, what is the probability that these biocontrol microbes will tolerate the stiff competition at the rhizosphere and adapt to the environmental condition? Would their competitive advantage (if any) enable them carryout their biocontrol activities in the soil? Many a time, an effective microbe at the laboratory or controlled laboratory experiment is usually a failure or ineffective under field condition.

On the other hand, root-associated beneficial microbes (Pseudomonas simiae WCS417) capable of inducing plant systemic resistance and also boost its growth are able to perform this function by suppressing quite a number of plant's responses arising from its association with microbes. This is to enable it to interact mutually with the plant root without being interfered by the plant immune response at the root region (rhizosphere). The flagellin influenced the transcriptional activity of the plant. Microbial flagellin from live and dead microbes can equally elicit/trigger plant immune response (Stringlis et al. 2018). Microbes have the tendency to trigger plant immunity as well as promote its growth without anyone of these activities interfering with another (Huot et al. 2014). These unique characteristics of beneficial microbes could be exploited in disease control and management. Certain proteins are essential in the induction and expression of pathogenesis genes for a sustainable plant immunity. The protein of importance is NPR1 (known as non-expressor of pathogen-related gene1). They are transcriptional cofactor protein molecules that upon binding to the transcription factor (TGA) can enhance the transcription of salicylic acid pathogenesis genes (Tada et al. 2008; Cao et al. 1994). 


\section{Biocontrol microbes in fruit preservation}

Microbes have proven to be good candidates in the control of fruit spoilage organisms and hence useful in fruit preservation. For instance, Cryptococcus laurentii, a yeast capable of biocontrol of pathogen involved in postharvest fruit and vegetable spoilage, has encouraged the activation/priming of defense-related genes (salicylic and jasmonic acid signal pathways) and the expression of pathogenesis-related protein genes that together made cherry tomato resistant to $B$. cinerea and A. alternata infection of the fruit (Lai et al. 2018; Wei et al. 2016). Fruit preservation could be approached microbiologically by the application of antagonistic microbes that will prime the expression of pathogenesis-related genes in the fruit, raise the fruit immunity, and enable it to resist the infective action of the fruit spoilage organisms. Treatment of tomato with Clonostachys rosea excellently inhibited the pathogenic actions of $B$. cinerea on the fruit. C. rosea induced systemic resistance condition in the fruit as observed with the elevated level of indole acetic acid (IAA), salicylic acid (SA), nitric oxide, phenylalanine ammonia lyase (PAL), and polyphenol oxidase (PPO) and decreased the concentration of catalase (CAT) and abscisic acid (ABA) (Gong et al. 2017). However, utilization of microbes in the control of fruit spoilage organisms for an increase in fruits' shelf life has raised quite a number of issues. What is the likelihood that these microbes will not constitute an environmental hazard as well as posse health-related challenges when used in fruit preservation? One of the major challenges that could limit the wider adoption of this phytopathogen control method is the possibility of microbial gene exchange in the environment. This requires that caution be applied to avoid pickup and transfer of virulent genes. Although this fruit preservation method is effective, the fact remains that until these issues are sorted out, using this method of fruit preservation in a commercial scale is full of risk.

\section{Systemic acquired resistance in plants: A second alternative}

Systemic acquired immunity usually occurs when a necrophilic/necrotizing pathogen (i.e., pathogens that cause cell death upon infection of a living cell/tissue) attack a plant, leading to the priming of pathogenesis-related genes responsible for this immune response to be activated. Systemic acquired resistance can as well be described as a wide-spectrum disease resistance of plant following a localized infection that transmit protection/immunity to secondary infection of the same or to a different microbial pathogen in an uninfected part of the plant. It is found that $\mathrm{NO}$ (nitric oxide) and $\mathrm{O}_{2}$ radical species are implicated in the induction/activation of systemic acquired resistance in plant via cleaving the $\mathrm{C} 9$ double bond of $\mathrm{C} 18$ unsaturated fatty acid whose product is azelaic acid (the inducer of systemic acquired resistance) (El-Shetehy et al. 2015). Also, the role of abscisic acid in the modulation of salicylic acid biosynthesis during tomato acquired systemic resistance is well documented by Kusajima et al. (2017).

At the gene level, induction of salicylic acid production during systemic acquired resistance by plant involves the transcription of the gene ICS1 (isochorismate synthase 1). Activation of this gene upon pathogen attack is controlled by the transcriptional factors NTL9 (NTM1-LIKE9) and CHE (CCA1 HIKING EXPEDITION) responsible for priming the ICS1 gene for immune responses to specific pathogen. Transcriptional factor NTL9 not only induces the expression of ICS1 but also the expression of PAD4 (phytoalexin deficient 4) and EDS1 (enhanced disease susceptibility 1) located within the guard cells of the leaves stomata where sensitization (Fig. 1) and expression of the gene help to boost the immunity and closure behavior of the stomata in response to pathogen presence (Zheng et al. 2015).

\section{Plant influence in soil immunity buildup}

Many soils harbor a consortium of both beneficial and pathogenic soilborne microbes but naturally through root exudate secretions, microbes could be either supported or starved depending on their ability to metabolize the exudates. As the number one major primary producers in the ecosystem, photosynthesis is the only means by which plants synthesize and supply labile carbon as well as poly-sugars to the soildwelling microbes. This gives them the influence over which organism should prevail and which to suppress through starvation. Aside from photosynthates injection into the soil, plants also introduce a number of antimicrobial substances that could inhibit the growth of certain microbes.

The actual plant protection and disease suppression inherent in the soil could equally be attributed to the rich diversity, structure, and function of viable microbes attracted and supported by the plants. These microbes will proliferate and outcompete the pathogenic microbes or may secrete antimicrobials into the soil to outwit their competitors, thereby indirectly making the soil healthy for crop production.

However, microbes have been implicated in the induction of plants' immune responses and protection from invasive pathogens. Yet the choice of which microbe to invite, support, and sustain is entirely dependent on the plants. Plants carry out these roles through their rhizosphere effects. This type of soil sustains the health of plants in spite of the presence or absence of soilborne pathogens. This "immune fortified" soil often occurs with agricultural practice of continuous cropping system involving planting the same crop such as wheat, sugar beet etc., in the same farmland till the soil enters a diseasesuppressive mode (Raaijmakers and Mazzola 2016). 
A. thaliana attracted Xanthomonas sp. (WCS2014-23), Stenotrophomonas sp. (WCS2014-113), and Microbacterium sp. (WCS2014-259) in a defense against the attack of the pathogen Hyaloperonospora arabidopsidis, the agent that causes downy mildew in plants. These microbes perform the enhancement of plant protection better as a team than as individual players in the rhizosphere (Berendsen et al. 2018).

\section{Endophytes in the activation of plants' immunity-systemic intrinsic resistance}

In an effort to survive and prevail in spite of the stiff competition among microbes particularly at the rhizosphere, some microbes possessing the cellulase enzyme capable of dissolving the cellulose cell wall of plant roots gain entrance into the apoplast of the plant that includes the interior of the cell wall as well as the vascular bundle - xylem, where they live and undergo normal metabolic activities. Any microbe able to gain entrance and dwell within the plant tissue is said to be an endophyte.

These microbes also have plant growth-promoting properties such as hormone production (Naveed et al. 2015) and deaminase enzyme production, etc., for supporting the host in the fight against invading microbes. The endophytes will continue to enjoy the aid the plants render to them until the plant is mechanically uprooted or die; however, during the life of the plant, both parties benefit (Miliute et al. 2015). The presence of these organisms does not, in any way, interrupt the proper functioning of the plant and so they are not pathogenic. Other microorganisms reside on the surface of the plant root exorhizosphere microbes and still perform their duty for the interest of the plant.

Biocontrol agents provide a pathogen control role by the production of secondary metabolites that inhibit the growth of the pathogen, by out competing them or induction of systemic resistance in the plant. Endophytes as well as non-endophytic microbes can adopt either of the methods mentioned above in the control of pathogens (O'hanlon et al. 2012). Two endophytic microbes (Diaporthe endophytica and Diaporthe terebinthifolii) exerted a biocontrol effect on Phyllosticta citricarpa (a fungus responsible for causing citrus black spot disease in citrus fruit). These biocontrol microbes were able to inhibit the pathogen via competition and colonization of the same citrus plant organ (niche) that the pathogenic fungus will seek to colonize and cause disease in the plant (Dos Santos et al., 2016).

Endophytes found in the seed of plants are likely to enter the seed through the connection of the vascular bundle, where they will ultimately colonize the embryo and/or endosperm. They could enter the plant seed via the reproductive part of the meristems (Malfanova et al. 2013). Endophytic bacteria isolated from wheat seeds promote vegetative plant growth through phytohormone (indole acetic acid) biosynthesis, siderophore, and/or phosphate solubilization. Also observed was its ability to form biofilms. Above all, they were effective in the inhibition of the fungal pathogen Fusarium graminearum. These endophytes included Paenibacillus sp. and Pantoea sp. (Herrera et al. 2016). The plant growthboosting rhizobacterium (Paenibacillus polymyxa AC-1) was implicated in the control/inhibition of the pathogens P. syringae (pv. Tomato DC 3000 ) and P. syringae (pv. tabaci). It was able to colonize the interior part of the A. thaliana plant and induce the expression of pathogenesisrelated genes (PR1, PDF1.2, WRKY29, FRK1) in the plant responsible for salicylic and jasmonic acid signaling and defense pathways in A. thaliana (Hong et al. 2016).

In the same vein, bacteria species identified as B. amyloliquefaciens (SB14), B. pumilus (SB6), Bacillus siamensis (AP2), and B. siamensis (AP8) isolated from the rhizosphere of sugar beet and root and shoot of apple and walnut plants controlled the disease of sugar beet dampingoff that is caused by $R$. solani (AG-4 and AG2-2). Among these isolates, $B$. amyloliquefaciens was the most effective biocontrol agent. However, solutions to every problem lie in the problem. This is supported by the observation that using native microbes associated with plants have higher chances of biocontrol success as a result of their environmental familiarity, adaptation, and easy adjustment to the host plant metabolites and the environmental conditions. This enables them to perform well in the fight against pathogens and foreign (allochthonous) microorganisms (Karimi et al. 2016).

From another perspective, the viral pathogen cucumber mosaic virus of tomato plants has been found to be controlled by Trichoderma harzianum through the mechanism of induced systemic resistance. T. harzianum primed the activation and expression of the defense genes for jasmonic acid, ethylene, and salicylic acid production in the tomato plants. It enhanced the growth of the plant, photosynthetic rate/ chlorophyll content as well as the gaseous exchange capacity of the inoculated plant (Vitti et al., 2015) providing a suitable alternative to the control of viral pathogen as chemical treatment of plants is ineffective in the control of viral pathogen (Vitti et al. 2015). The saprotrophic beneficial endophytic fungus T. harzianum T-78 via its efficient root colonization of tomato plant not only stop the penetration/invasion and multiplication of Meloidogyne incognita but also primed the activation of salicylic and jasmonic acid immune dependent signaling pathways in plant. This induction of pathogenesisrelated genes was in the presence of the pathogen which elicited the process by sensitizing the plant through pathogenassociated molecular pattern induction. At first, Trichoderma induced salicylic acid defense against the nematode and when the nematode imped the jasmonic acid signaling/expression in the plant root, the fungus quickly restored the suppressed jasmonic acid pathway and fortified the plant resistance to 
the nematode reproduction and proliferation (MartınezMedina et al., 2016).

The molecular approach through which T. harzianum induces systemic resistance in plants involves the expression of hydrolase genes Thph1 and Thph 2 that is controlled by Thc6 (C6 zinc finger protein). These gene products (Thph1 and Thph2) prime the production of ROS (reactive oxygen species) and increased the cytoplasmic calcium content of maize leaf. They equally increased the expression of the jasmonic acid/ ethylene defense signaling pathway in the non-genetic modified maize plant for efficient protection against the disease (Saravanakumar et al., 2016). The colonization of maize plant by $T$. harzianum induced the plant's systemic resistance to the pathogen Curvularia lunata by priming the expression of the gene PAF-AH (platelet activating factor acetylhydrolase). This activation factor produced by the fungus primed the expression and production of chitinase and cellulase enzyme including jasmonic acid inducible genes. The intracellular activities breed and enhance the resistance of maize to the pathogen (Yu et al. 2015).

\section{Elicitors in the induction of systemic resistance to biotic stress in plants}

Elicitors are natural or synthesized chemicals either from microbial origin or chemical combination of elements (Table 2) that are capable of initiating systemic resistance action in plants against pathogens when applied. They could cause a physiological condition of programmed cell death/apoptosis (Heath, 1998). Apoptosis could be caused by invasive pathogen attack on plants whose influence increase the intracellular level of reactive oxygen species and initiate calcium buildup within the plant cell that results in apoptotic cell death (Li et al. 2018).

Exogenous and endogenous salicylic acids are important in gene priming for systemic resistance/protection of plants against pathogens. Exogenous applied salicylic acid on tomato plant has induced the activation of genes responsible for pathogenesis and protection of plant. This substance hindered root infection by $M$. incognita and boosted the resistance of the plant to the nematode (Molinari et al. 2014).

A variety of metabolites produced by Azospirillum brasilense (V5 and V6) which comprises of IAA, indole-3ethanol (IEA), indole-3-lactic acid (ILA), and SA promoted the increased expression of oxidative stress genes and pathogenesis-related genes in the leave and root parts of the maize plant. Application of the metabolites and live bacteria on the leaves of maize equally enhanced plant growth as a result of the phytohormone produced and priming of plant defense genes (Fukami et al. 2017; Vacheron et al. 2015).

Also implicated in the protection of plant against pathogen is the volatile organic compounds produced by beneficial rhizomicrobes (Table 2) which performs their role by the initiation of systemic resistance in the plants. Volatile organic compounds are gaseous, low molecular weight organic compounds such as albuterol, 1,3-propanediol (Tahir et al. 2017), 3-pentanol, and 2-butanone (Song and Ryu 2013) which can activate the plant immune system and imped pathogenic microbes from a distance. For this type of compound, distance is never a barrier to its action compared with other chemical substances of higher molecular weight like exopolysaccharide and proteins that are involved in pathogen control which acts only in close proximity/contact with the plant (Yunus et al. 2016; Xie et al. 2014; Raza et al. 2016).

Also, an important organic compound produced by the organism Enterobacter aerogenes was good in boosting the resistance of maize to the attacking fungus Setosphaeria turcica (a leaf blight-causing fungus). In as much as this organic compound (2,3 butanediol) produced by E. aerogenes has a remarkable effect in plant resistance to blight-causing fungus, it does not necessarily contribute to the resistance of the maize plant to parasitoid (Cotesia marginiventris) attack, yet when applied to the soil as an amendment act as an attractant of the microbe to the plant root. But the attraction is inhibited in the presence of the organism (E. aerogenes) (Table 3) (D'Alessandro et al. 2014). On the other hand, the analogue of salicylic and jasmonic acid facilitates the activation/initiation of systemic resistance in treated tobacco plant. It equally protects the plant against tobacco mosaic viral infection by priming the activation and expression of the genes responsible for plant systemic protection. Tobacco plants that bear defective salicylic and jasmonic acid genes increased the infectivity and/or susceptibility of tobacco plant to the viral infection (Zhu et al. 2014).

The volatile organic compound 2,3-butanediol has two enantiomers $(2 \mathrm{R}, 3 \mathrm{R}$ and $2 \mathrm{~S}, 3 \mathrm{~S})$ and a meso-type (2R3S) butanediol produced by root-associated beneficial microbes are implicated in the systemic resistance induction in pepper against cucumber mosaic virus (CMV) and tobacco mosaic virus (TMV). Among the three isomers, $2 \mathrm{R}, 3 \mathrm{R}$ and $2 \mathrm{R}, 3 \mathrm{~S}$, butanediols were the most effective in priming salicylic acid, jasmonic acid, and ethylene defense genes in the plant (Kong et al. 2018).

However, the application of Beta aminobutyric acid (BABA) (a non-protein amino acid elicitor) and non-host Phytophthora nicotianae on chili peppers induced systemic resistance of the plants to the pathogen Phytophthora capsici. These elicitors influenced the plant by reducing plant cellular sucrose concentration as well as tricarboxylic acid cycle intermediates. It also boosted the concentration of hexose phosphate, hexose disaccharides, amino acids, and galactose in the induced plant, thereby building the plant immunity against Phytophthora capsici (Stamler et al. 2015).

The dead cells surrounding the area of infection will block the migration of the pathogen from point of infection to other points in the plant. This is to encourage the production of 
Table 2 The influence of biological and chemical elicitors in plant protection against pathogens

\begin{tabular}{|c|c|c|c|c|}
\hline Elicitors/inducers & Plants & Phytopathogens & Priming actions of elicitor in plants & References \\
\hline Azelaic acid AZA1 & Arabidopsis & $\begin{array}{l}\text { Pseudomonas syringae } \\
\text { pv. maculicola } \\
\text { ES4326 }\end{array}$ & $\begin{array}{l}\text { Defense genes enabled the movement of } \\
\text { AZA by binding to lipid-AZA and } \\
\text { induced systemic resistance in the plant }\end{array}$ & $\begin{array}{l}\text { Cecchini et al. } \\
\text { (2015) }\end{array}$ \\
\hline Ammonium ion $\left(\mathrm{NH}_{4}{ }^{+}\right)$ & Tomato & $\begin{array}{l}\text { Pseudomonas syringae } \\
\text { pv. tomato DC } 3000\end{array}$ & $\begin{array}{l}\text { Improved the accumulation of hydrogen } \\
\text { peroxide which triggered the abscicis } \\
\text { acid signaling pathway and induced } \\
\text { the closure of stomata as well as } \\
\text { accumulation of putrescine in the plant }\end{array}$ & $\begin{array}{l}\text { Fernández-Crespo } \\
\text { et al. (2015) }\end{array}$ \\
\hline PeBA1 protein & Tobacco & $\begin{array}{l}\text { Tobacco mosaic virus, } \\
\text { Botrytis cinerea }\end{array}$ & $\begin{array}{l}\text { Induced defensive genes for the } \\
\text { production of salicylic acid, phenylalanine } \\
\text { ammonia lyase, jasmonic acid, hydrogen } \\
\text { peroxide, and phenolic compounds }\end{array}$ & Wang et al. (2016) \\
\hline Benzothiadiazole & Tomato & $\begin{array}{l}\text { Tomato spotted wilt } \\
\text { virus and citrus } \\
\text { exocortis viroid }\end{array}$ & $\begin{array}{l}\text { Activated the salicylic acid signaling } \\
\text { pathway and improved the plant } \\
\text { resistance to the viral infection }\end{array}$ & $\begin{array}{l}\text { Lopez-Gresa } \\
\text { et al. (2016) }\end{array}$ \\
\hline Benzothiadiazole & Sunflower & Sclerotinia sclerotiorum & $\begin{array}{l}\text { Hindered the development of fungal } \\
\text { hyphae in the plant and increased } \\
\text { the establishment of mycorrhizae } \\
\text { in the plant root }\end{array}$ & Ban et al. (2017) \\
\hline Methyl jasmonate & Whitebark pine & $\begin{array}{l}\text { Cronartium ribicola } \\
\text { mountain pine beetle } \\
\text { (MBP, Dendroctonus } \\
\text { ponderosae) }\end{array}$ & $\begin{array}{l}\text { It triggered the plant reprogramming } \\
\text { of the transcriptome profile, a set } \\
\text { of DEG (differentially expressed } \\
\text { genes) associated with plant defense } \\
\text { signaling, etc. }\end{array}$ & Liu et al. (2017) \\
\hline $\begin{array}{l}\text { Salicylic acid or } \\
\text { methyl jasmonate }\end{array}$ & Cassava & $\begin{array}{l}\text { Xanthomonas } \\
\text { axonopodis } \\
\text { pv. manihotis }\end{array}$ & $\begin{array}{l}\text { Elevated the defense action of cassava } \\
\text { plant to the bacterial pathogen }\end{array}$ & Yoodee et al. (2018) \\
\hline Benzoylsalicylic acid & $\begin{array}{l}\text { Tobacco, } \\
\text { Arabidopsis }\end{array}$ & Tobacco mosaic virus & $\begin{array}{l}\text { It enhanced plant resistance to the virus } \\
\text { and induce the expression of } \\
\text { non-expressor of pathogenesis-related } \\
\text { gene } 1 \text { (NPR1), hypersensitivity-related } \\
\text { molecules, mitogen activated protein } \\
\text { kinase (MARK) as well as WRKY } \\
\text { genes in the plant }\end{array}$ & $\begin{array}{l}\text { Kamatham } \\
\text { et al. (2016) }\end{array}$ \\
\hline Ningnanmycin & Tobacco & Tobacco mosaic virus & $\begin{array}{l}\text { Inhibited polymerization of tobacco } \\
\text { mosaic virus protein coat and } \\
\text { induced systemic resistance and } \\
\text { accumulation of pathogenesis-related } \\
\text { proteins in the plant }\end{array}$ & Han et al. (2014) \\
\hline $\begin{array}{l}\text { 3-Acetonyl-3-hydroxyoxindole } \\
\text { (AHO) }\end{array}$ & $\begin{array}{l}\text { Nicotiana } \\
\quad \text { tabacum }\end{array}$ & Tomato spotted wilt virus & $\begin{array}{l}\text { Induced the activation of differentially } \\
\text { expressed genes (PR1 and PR10) } \\
\text { that facilitated the priming and } \\
\text { expression of metabolic pathways for } \\
\text { synthesis of phenyl propanoid, } \\
\text { sesquiterpenoid, triterpenoid for } \\
\text { protecting plant cuticle, and wax }\end{array}$ & Chen et al. (2017) \\
\hline $\begin{array}{l}\text { N-decanoyl-homoserine } \\
\text { lactone }\end{array}$ & Tomato & Botrytis cinerea & $\begin{array}{l}\text { Induced plant jasmonic acid biosynthesis } \\
\text { and signal transduction in the treated } \\
\text { tomato plant which confer resistance } \\
\text { to the fungal infection }\end{array}$ & Hu et al. (2018) \\
\hline PevD1 & $\begin{array}{l}\text { Nicotiana } \\
\text { benthamiana }\end{array}$ & $\begin{array}{l}\text { Verticillium dahliae, } \\
\text { Tobacco mosaic virus, } \\
\text { Pseudomonas } \\
\text { syringae pv. tabaci }\end{array}$ & $\begin{array}{l}\text { Interacted with asparagine-rich protein } \\
\text { (Nbnrp1) to regulate PevD1 that is } \\
\text { associated with induction of cell death } \\
\text { and increased the plant resistance to the vi- } \\
\text { rus }\end{array}$ & Liang et al. (2018) \\
\hline
\end{tabular}

antimicrobial substances that will impede the proliferation of the pathogen (Hammerschmidt, 1999). Exogenous application of synthetic salicylic acid and beta aminobutyric acid (in a concentration of 1.5 and $15 \mathrm{mM}$, respectively) was found to induce the activation of the pathogenesis-related protein production of chitinase enzyme as well as beta 1,3-glucanase for 
Table 3 Influence of direct microbe-plant association in plant protection

\begin{tabular}{|c|c|c|c|c|}
\hline Microbes & Compounds produced in plants & Invading pathogens & Plants & References \\
\hline Azotobacter sp., Pseudomonas sp. & Beta 1,3-glucanase, peroxidase & Cucumber mosaic virus & Cucumber & $\begin{array}{l}\text { El-Borollosy and } \\
\text { Oraby (2012) }\end{array}$ \\
\hline Bacillus cereus AR156 & $\begin{array}{l}\text { Hydrogen peroxide, } \\
\text { pathogenesis-related protein }\end{array}$ & Pseudomonas syringae pv. tomato & Arabidopsis & Niu et al. (2016) \\
\hline $\begin{array}{l}\text { Pseudomonas putida } \\
\text { CRN-09, Bacillus } \\
\text { subtilis } \text { CRN-16 }\end{array}$ & $\begin{array}{l}\text { Peroxidase, polyphenol oxidase, } \\
\text { phenylalanine ammonia lyase, } \\
\text { beta 1,3-glucanase, chitinases }\end{array}$ & Macrophomina phaseolina & Mung bean & Sharma et al. (2018) \\
\hline Paenibacillus sp. P16 & $\begin{array}{l}\text { Induced systemic resistance in } \\
\text { cabbage plant }\end{array}$ & $\begin{array}{l}\text { Xanthomonas campestris pv. } \\
\text { campestris }\end{array}$ & Cabbage & Ghazalibiglar et al. (2016) \\
\hline Bacillus amyloliquefaciens & $\begin{array}{l}\text { Production of peroxidase, } \\
\text { polyphenol oxidase, and } \\
\text { expression of pathogenesis-related } \\
\text { genes for (jasmonic and } \\
\text { salicylic acids) }\end{array}$ & Ralstonia solanacearum & Tomato & Li et al. (2017) \\
\hline Pseudomonas sp. (BaC1-38) & Beta 1,3-glucanase, chitinases & Xanthomonas campestris & Rice & Lucas et al. (2014) \\
\hline
\end{tabular}

effective immunity and resistance of tomato plant to the invasive pathogen Alternaria solani (Raut and Borkar, 2014). Also, hydrogen peroxide, abscisic acid, and 2,4 dichlorophenoxy acetic acid chemical inducers applied exogenously to potato plant challenged with $A$. solani was able to resist the pathogen infection as a result of increase in plant intracellular concentration of peroxidase, phenylalanine ammonia lyase, and polyphenoloxidase enzymes. These synthesized enzymes inhibited the invasion of $A$. solani in tomato plant (Nassar and Adss 2016).

Calcium treatment of plants is another abiotic approach to enhancing plant resistance to biotic stress. Calcium has been found to boost the activities of peroxidase and strengthen the plant cell wall as well as improve the production of substance that could inhibit fungi development on plant (Clark 2013; Xu et al. 2013; Downie, 2014). A combined treatment of tomato plant with calcium salt and salicylic acid elevated the production of antioxidant proteins, chitinase, and pathogenesisrelated proteins that encouraged tomato resistance to B. cinerea infection (Linlin et al. 2016).

Another elicitor that is eco-friendly and effective in induction of plant resistance to pathogens include plant extract. Plant extract-limonoids (Munronin O)_obtained from the plant of Munronia henryi Harms is effective in protecting tobacco plants against the tobacco mosaic virus by enhancing the defense enzyme production and salicylic acid level of the treated tobacco plant and induced systemic acquired resistance in the plant (Yan et al. 2018). And the interaction of these chemical with soil humus or particles leave a big doubt concerning their possibility of being biodegradable when they form stable complexes with the soil particles. Therefore, caution must be applied in the use of these chemical analogues to boost plant immunity. However, natural elicitors such as plant extracts and microbial metabolites use should be encouraged. But the challenge remains that the cost of producing these natural organic elicitors as well as their preservation could be quite expensive.

\section{Conclusion}

The use of pesticides to control plant pathogens and pests cause issues of concern as the majority of the agrochemicals used in biocontrol not only lower the disease severity in the plant but also lower the yield of the crop (Egel et al. 2018). Some of these chemicals can be harmful to human and animals and may constitute environmental pollution. Carbamate and pyrethoid (insecticides) can cause secondary outbreaks of pests such as aphids (Egel et al. 2018). This necessitates the search for a suitable and eco-friendly alternative in disease control and management.

The use of microbes capable of antagonistic behavior against pathogens for induction of systemic resistance in plant is a good method in crop disease management (Babalola 2010). Also, the application of elicitors either in a drench form or foliar spray on plants is yet another method of pathogen control. Elicitors are capable of inducing the expression and/ or activation of pathogenesis-related-genes and improving the immunity of the treated plant for efficient fight against invaders.

However, to achieve a maximum protection of plant against pathogens, an integrated disease management and control approach that will involve the use of microbes, its metabolites, synthetic chemicals, and plant extracts formulation that will be simultaneously applied to the plant will enable farmers win the war against plant pathogens, increase crop yield, and achieve a sustainable agricultural practice in ensuring food security. 
Acknowledgements MCE is supported by the NRF-TWAS/African Renaissance Doctoral Scholarship. This work is based on the research supported by the National Research Foundation of South Africa (Grants Ref: UID81192, UID95111; OOB).

Funding The study was funded by the National Research Foundation of South Africa (Grants Ref: UID81192, UID95111; OOB) and the South Africa's National Research Foundation/The World Academy of Science African Renaissance Scholarship (NRF-TWAS/African Renaissance Doctoral Scholarship).

\section{Compliance with ethical standards}

Conflict of interest The authors declare that they have no conflict of interest.

Ethical approval This article does not contain any studies with human participants or animals performed by any of the authors.

Open Access This article is distributed under the terms of the Creative Commons Attribution 4.0 International License (http:// creativecommons.org/licenses/by/4.0/), which permits unrestricted use, distribution, and reproduction in any medium, provided you give appropriate credit to the original author(s) and the source, provide a link to the Creative Commons license, and indicate if changes were made.

\section{References}

Adam M, Heuer H, Hallmann J (2014) Bacterial antagonists of fungal pathogens also control root-knot nematodes by induced systemic resistance of tomato plants. PLoS One 9(2):e90402. https://doi.org/ 10.1371/journal.pone.0090402

Akram W, Anjum T, Ali B (2016) Phenylacetic acid is ISR determinant produced by Bacillus fortis iags162, which involves extensive remodulation in metabolomics of tomato to protect against Fusarium wilt. Front Plant Sci 7:498. https://doi.org/10.3389/fpls.2016.00498

Ali S, Mir ZA, Tyagi A, Mehari H, Meena RP, Bhat JA, Yadav P, Papalou P, Rawat S, Grover A (2017) Overexpression of npr1 in Brassica juncea confers broad spectrum resistance to fungal pathogens. Front Plant Sci 8:1693. https://doi.org/10.3389/fpls.2017.01693

Arseneault T, Goyer C, Filion M (2015) Pseudomonas fluorescens LBUM223 increases potato yield and reduces common scab symptoms in the field. Phytopathol 105:1311-1317

Asari S, Ongena M, Debois D, De Pauw E, Chen K, Bejai S, Meijer J (2017) Insights into the molecular basis of biocontrol of Brassica pathogens by Bacillus amyloliquefaciens UCMB5113 lipopeptides. Ann Bot 120:551-562. https://doi.org/10.1093/aob/mcx089

Ashwin NMR, Barnabas EL, Ramesh Sundar A, Muthumeena M, Malathi P, Viswanathan R (2017) Disease suppressive effects of resistance-inducing agents against red rot of sugarcane. Eur J Plant Pathol 149:285-297. https://doi.org/10.1007/s10658-017-1181-1

Ashwin NMR, Barnabas L, Ramesh Sundar A, Malathi P, Viswanathan R, Masi A, Agrawal GK, Rakwal R (2018) CfPDIP1, a novel secreted protein of Colletotrichum falcatum, elicits defense responses in sugarcane and triggers hypersensitive response in tobacco. Appl Microbiol Biotechnol pp. 1 - 21. doi:https://doi.org/10.1007/ s00253-018-9009-2, 102, 6021

Babalola OO (2010) Beneficial bacteria of agricultural importance. Biotechnol Lett 32(11):1559-1570

Babalola OO (2014) Does nature make provision for backups in the modification of bacterial community structures? Biotech Genetic
Eng Rev 30(1):31-48. https://doi.org/10.1080/02648725.2014. 921497

Bán R, Baglyas G, Virányi F, Barna B, Posta K, Kiss J, Körösi K (2017) The chemical inducer, BTH (benzothiadiazole) and root colonization by mycorrhizal fungi (Glomus spp.) trigger resistance against white rot (Sclerotinia Sclerotiorum) in sunflower. Acta Biol Hung 68(1):50-59. https://doi.org/10.1556/018.68.2017.1.5

Berendsen RL, Pieterse CMJ, Bakker PAHM (2012) The rhizosphere microbiome and plant health. Trends Plant Sci 17:478-486

Berendsen RL, Vismans G, Yu K, Song Y, de Jonge R, Burgman WP, Burmolle M, Herschend J, Bakker PAHM, Pieterse CMJ (2018) Disease-induced assemblage of a plant-beneficial bacterial consortium. ISME J 12:1496-1507

Blainski JML, da Rocha Neto AC, Schimidt EC, Voltolini JA, Rossi MJ, Di Piero RM (2018) Exopolysaccharides from Lactobacillus plantarum induce biochemical and physiological alterations in tomato plant against bacterial spot. Appl Microbiol Biotechnol 1-13. https://doi.org/10.1007/s00253-018-8946-0, 102

Böhm H, Albert I, Fan L, Reinhard A, Nürnberger T (2014) Immune receptor complexes at the plant cell surface. Curr Opin Plant Biol 20C:47-54. https://doi.org/10.1016/j.pbi.2014.04.007

Bu B, Qiu D, Zeng H, Guo L, Yuan J, Yang X (2014) A fungal protein elicitor PevD1 induces Verticillium wilt resistance in cotton. Plant Cell Rep 33:461-470. https://doi.org/10.1007/s00299-013-1546-7

Caarls L, Elberse J, Awwanah M, Ludwig NR, de Vries M, Zeilmaker T, Van Wees SCM, Schuurink RC, den Ackerveken GV (2017) Arabidopsis jasmonate-induced oxygenases down-regulate plant immunity by hydroxylation and inactivation of the hormone jasmonic acid. PNAS pp. 1-6. https://doi.org/10.1073/pnas. 1701101114

Cao H, Bowling SA, Gordon AS, Dong X (1994) Characterization of an Arabidopsis mutant that is nonresponsive to inducers of systemic acquired resistance. Plant Cell 6:1583-1592. https://doi.org/10. $1105 /$ tpc.6.11.1583

Cawoy H, Mariutto M, Henry G, Fisher C, Vasilyeva N, Thonart P, Dommes J, Ongena M (2014) Plant defense stimulation by natural isolates of Bacillus depends on efficient surfactin production. Mol Plant Microbe Interac 27(2):87-100. https://doi.org/10.1094/ MPMI-09-13-0262-R

Cecchini NM, Steffes K, Schlappi MR, Gifford AN, Greenberg JT (2015) Arabidopsis AZI1 family proteins mediate signal mobilization for systemic defence priming. Nature Commun 6:7658. https://doi.org/ $10.1038 /$ ncomms 8658

Chang Y-H, Yan H-Z, Liou R-F (2014) A novel elicitor protein from Phytophthora parasitica induces plant basal immunity and systemic acquired resistance. Mol Plant Pathol pp. 1-14. https://doi.org/10. 1111/mpp.12166

Chen Y, Dong J, Bennetzen JL, Zhong M, Yang J, Zhang J, Li S, Hao X, Zhang Z, Wang X (2017) Integrating transcriptome and microRNA analysis identifies genes and microRNAs for AHO-induced systemic acquired resistance in N. tabacum. Scientific Rep 7:12504. Doi: https://doi.org/10.1038/s41598-017-12249-y

Clark KB (2013) Biotic activity of $\mathrm{Ca}^{2+}$ - modulating non-traditional antimicrobial and -viral agents. Front Microbiol 4:381

Constantino NN, Mastouri F, Damarwinasis R, Borrego JE, Moran-Diez ME, Kenerley CM, Gao X, Kolomiets MV (2013) Root-expressed maize lipoxygenase 3 negatively regulates induced systemic resistance to Colletotrichum graminicola in shoots. Front Plant Sci 4(510):1-12. https://doi.org/10.3389/fpls.2013.00510

Crouzet J, Roland J, Peeters E, Trombik T, Ducos E, Nader J, Boutry M (2013) NtPDR1, a plasma membrane ABC transporter from Nicotiana tabacum, is involved in diterpene transport. Plant Mol Biol 82:181-192

D'Alessandro M, Erb M, Ton J, Brandenburg A, Karlen D, Zopfi J, Turlings TCJ (2014) Volatiles produced by soil-borne endophytic bacteria increase plant pathogen resistance and affect tritrophic 
interactions. Plant Cell Environ 37(4):813-826. https://oi.org/10. 1111 pce. 12220

Dey S, Wenig M, Langen G, Sharma S, Kugler KG, Knappe C, Hause B, Bichlmeier M, Babaeizad V, Imani J, Janzik I, Stempfl T, Hückelhoven R, Kogel K-H, Mayer KFX, Corina Vlot A (2014) Bacteria-triggered systemic immunity in barley is associated with WRKY and ethylene responsive factors but not with salicylic acid1[C][W]. Plant Physiol 166:2133-2151

Ding T, Su B, Chen X, Xie S, Gu S, Wang Q, Huang D, Jiang H (2017) An endophytic bacterial strain isolated from Eucommia ulmoides inhibits southern corn leaf blight. Front Microbiol 8:903. https:// doi.org/10.3389/fmicb.2017.00903

Dos Santos PJC, Savi DC, Gomes RR, Goulin EH, Senkiv CDC, Tanaka FAO, Almeida ÁMR, Galli-Terasawa L, Kava V, Glienke C (2016) Diaporthe endophytica and D. terebinthifolii from medicinal plants for biological control of Phyllosticta citricarpa. Microbiol Res 186187:153-160

Downie JA (2014) Calcium signals in plant immunity: a spiky issue. New Phytol 204:733-735

Egel DS, Kleczewski NM, Mumtaz F, Foster R (2018) Acibenzolar-Smethyl is associated with yield reduction when used for managing bacterial wilt (Erwinia tracheiphila) in cantaloupe. Crop Prot 109: 136-141

El-Borollosy AM, Oraby MM (2012) Induced systemic resistance against cucumber mosaic cucumovirus and promotion of cucumber growth by some plant growth-promoting rhizobacteria. Ann Agric Sci 57(2):91-97

El-Shetehy M, Wang C, Shine MB, Yu K, Kachroo A, Kachroo P (2015) Nitric oxide and reactive oxygen species are required for systemic acquired resistance in plants. Plant Signal Behav 10(9):e998544

Farace G, Fernandez O, Jacquens L, Coutte F, Krier F, Jacques P, Clement C, Barka EA, Jacquard C, Dorey S (2014) Cyclic lipopeptides from Bacillus subtilis activate distinct patterns of defence responses in grapevine. Mol Plant Pathol 16:1-11. https://doi.org/10.1111/mpp. 12170

Fatima S, Anjum T (2017) Identification of a potential ISR determinant from Pseudomonas aeruginosa PM12 against Fusarium wilt in tomato. Front Plant Sci 8:848. https://doi.org/10.3389/fpls.2017. 00848

Fernández-Crespo E, Scalschi L, Llorens E, García-Agustín P, Camañes $\mathrm{G}$ (2015) $\mathrm{NH}_{4}{ }^{+}$protects tomato plants against Pseudomonas syringae by activation of systemic acquired acclimation. J Exp Bot 66(21):6777-6790. https://doi.org/10.1093/jxb/erv382

Ferraz HB, Bertolucci PH, Pereira JS, Lima JG, Andrade LA (1988) Chronic exposure to the fungicide maneb may produce symptoms and signs of CNS manganese intoxication. Neurol 38:550-553

Figueredo MS, Tonelli ML, Ibánez F, Morla F, Cerioni G, Tordable MC, Fabra A (2017) Induced systemic resistance and symbiotic performance of peanut plants challenged with fungal pathogens and coinoculated with the biocontrol agent Bacillus sp. CHEP5 and Bradyrhizobium sp. SEMIA6144. Microbiol Res 197:65-73

Fujita M, Kusajima M, Okumura Y, Nakajima M, Minamisawa K, Nakashita H (2017) Effects of colonization of a bacterial endophyte, Azospirillum sp. B510, on disease resistance in tomato. Biosci Biotechnol Biochem : https://doi.org/10.1080/09168451.2017. 1329621

Fukami J, Ollero FJ, Megías M, Hungria M (2017) Phytohormones and induction of plant-stress tolerance and defense genes by seed and foliar inoculation with Azospirillum brasilense cells and metabolites promote maize growth. AMB Express 7:153. https://doi.org/10. 1186/s13568-017-0453-7

Fukasawa-Akada T, Kung S, Watson JA (1996) Phenylalanine ammonia lyase gene structure, expression, and evolution in Nicotiana. Plant Mol Biol 30:711-722
Ghazalibiglar H, Hampton JG, de Jong EvZ, Holyoake A (2016) Is induced systemic resistance the mechanism for control of black rot in Brassica oleracea by a Paenibacillus sp.? Biol Control 92:195-201

Glaeser SP, Imani J, Alabid I, Guo H, Kumar N, Kämpfer P, Hardt M, Blom J, Goesmann A, Rothballer M, Hartmann A, Kogel K-H (2016) Non-pathogenic Rhizobium radiobacter F4 deploys plant beneficial activity independent of its host Piriformospora indica. ISME J 10:871-884

Gond SK, Bergen MS, Torres MS, White Jr JF (2015) Endophytic Bacillus spp. produce antifungal lipopeptides and induce host defence gene expression in maize. Microbiol Res 172:79-87

Gong C, Liu Y, S-y L, M-z C, Zhang Y, Wang R-h, H-y C, Li J-f, X-1 C, A-x W (2017) Analysis of Clonostachys rosea-induced resistance to grey mould disease and identification of the key proteins induced in tomato fruit. Postharvest Biol Technol 123:83-93

Gruau C, Trotel-Aziz P, Villaume S, Rabenoelina F, Clement C, Baillieul F, Aziz A (2015) Pseudomonas fluorescens PTA-CT2 triggers local and systemic immune response against Botrytis cinerea in grapevine. MPMI 28(10):1117-1129. https://doi.org/10.1094/MPMI-0415-0092-R

Haidar R, Roudet J, Bonnard O, Dufour MC, Corio-Costet MF, Fert M, Gautier T, Deschamps A, Fermaud M (2016) Screening and modes of action of antagonistic bacteria to control the fungal pathogen Phaeomoniella chlamydospora involved in grapevine trunk diseases. Microbiol Res 192:172-184

Hammerschmidt R (1999) Induced disease resistance: how do induced plants stop pathogens? Physiol Mol Plant Pathol 55:77-84

Hammerschmidt R, Nuckles EM, Kuc J (1982) Association of enhanced peroxidase activity with induced systemic resistance of cucumber to Colletotrichum lagenarium. Physiol Plant Pathol 20:73-83

Han Y, Luo Y, Qin S, Xi L, Wan B, Du L (2014) Induction of systemic resistance against tobacco mosaic virus by Ningnanmycin in tobacco. Pestic Biochem Physiol 111:14-18

Hariprasad P, Chandrashekar S, Brijesh Singh S, Niranjana SR (2013) Mechanisms of plant growth promotion and disease suppression by Pseudomonas aeruginosa strain 2apa. J Basic Microbiol 00:1-10. https://doi.org/10.1002/jobm.201200491

Heath MC (1998) Apoptosis, programmed cell death and the hypersensitive cell death. Eur J Plant Pathol 104:117-124

Herrera SD, Grossi C, Zawoznik M, Groppa MD (2016) Wheat seeds harbour bacterial endophytes with potential as plant growth promoters and biocontrol agents of Fusarium graminearum. Microbiol Res 186-187:37-43

Hong CE, Kwon SY, Park JM (2016) Biocontrol activity of Paenibacillus polymyxa AC-1 against Pseudomonas syringae and its interaction with Arabidopsis thaliana. Microbiol Res 185:13-21

Hsu C-K, Micallef SA (2017) Plant-mediated restriction of Salmonella enterica on tomato and spinach leaves colonized with Pseudomonas plant growth-promoting rhizobacteria. Int J Food Microbiol 259:1-6

Hu Z, Shao S, Zheng C, Sun Z, Shi J, Yu J, Qi Z, Shi K (2018) Induction of systemic resistance in tomato against Botrytis cinerea by Ndecanoyl-homoserine lactone via jasmonic acid signaling. Planta 247:1217-1227. https://doi.org/10.1007/s00425-018-2860-7

Huot B, Yao J, Montgomery BL, He SY (2014) Growth-defense tradeoffs in plants: a balancing act to optimize fitness. Mol Plant 7:1267-1287

Jiang C-H, Huang Z-Y, Xie P, Gu C, Li K, Wang D-C, Yu Y-Y, Fan Z-H, Wang C-J, Wang Y-P, Guo Y-H, Guo J-H (2015) Transcription factors WRKY70 and WRKY11 served as regulators in rhizobacterium Bacillus cereus AR156-induced systemic resistance to Pseudomonas syringae pv. Tomato DC3000 in Arabidopsis. J Exp Bot1-18. Doi:https://doi.org/10.1093/jxb/erv445, 67, 157, 174

Kamatham S, Neela KB, Pasupulati AK, Pallu R, Singh SS, Gudipalli P (2016) Benzoylsalicylic acid isolated from seed coats of Givotia rottleriformis induces systemic acquired resistance in tobacco and Arabidopsis. Phytochem 126:11-22 
Karimi E, Safaie N, Shams-Baksh M, Mahmoudi B (2016) Bacillus amyloliquefaciens SB14 from rhizosphere alleviates Rhizoctonia damping-off disease on sugar beet. Microbiol Res 192:221-230

Khare D, Choi H, Huh SU, Bassin B, Kim J, Martinoia E, Sohn KH, Paek K-H, Lee Y (2017) Arabidopsis ABCG34 contributes to defense against necrotrophic pathogens by mediating the secretion of camalexin. PNAS 114:1-9. https://doi.org/10.1073/pnas. 1702259114

Kim J-S, Lee J, Lee C-H, Woo SY, Kang H, Seo S-G, Kim S-H (2015) Activation of pathogenesis-related genes by the rhizobacterium, Bacillus sp. JS, which induces systemic resistance in tobacco plants. Plant Pathol J 31(2):195-201

Kong HG, Shin TS, Kim TH, Ryu C-M (2018) Stereoisomers of the bacterial volatile compound 2,3-Butanediol differently elicit systemic defense responses of pepper against multiple viruses in the field. Front Plant Sci 9:90. https://doi.org/10.3389/fpls.2018.00090

Kusajima M, Okumura Y, Fujita M, Nakashita H (2017) Abscisic acid modulates salicylic acid biosynthesis for systemic acquired resistance in tomato. Biosci Biotechnol Biochem 81:1850-1853. https://doi.org/10.1080/09168451.2017.1343121

Lai Y-R, Lin P-Y, Chen C-Y, Huang C-J (2016) Feasible management of southern corn leaf blight via induction of systemic resistance by Bacillus cereus $\mathrm{C} 1 \mathrm{~L}$ in combination with reduced use of dithiocarbamate fungicides. Plant Pathol J 32(5):481-488. https://doi.org/10. 5423/PPJ.OA.02.2016.0044

Lai J, Cao X, Yu T, Wang Q, Zhang Y, Zheng X, Lu H (2018) Effect of Cryptococcus laurentii on inducing disease resistance in cherry tomato fruit with focus on the expression of defense-related genes. Food Chem 254:208-216

Lamdan N-L, Shalaby S, Ziv T, Kenerley CM, Horwitz BA (2015) Secretome of Trichoderma interacting with maize roots: role in induced systemic resistance. Mol Cell Proteomics 14:1054-1063. https://doi.org/10.1074/mcp.M114.046607

Lee BD, Dutta S, Ryu H, Yoo S-J, Suh D-S, Park K (2015) Induction of systemic resistance in Panax ginseng against Phytophthora cactorum by native Bacillus amyloliquefaciens HK34. J Ginseng Res 39:213-220

Lee G, Lee S-H, Kim KM, Ryu C-M (2017) Foliar application of the leafcolonizing yeast Pseudozyma churashimaensis elicits systemic defense of pepper against bacterial and viral pathogens. Sci Rep 7: 39432. https://doi.org/10.1038/srep39432

Li CY, Hu WC, Pan B, Liu Y, Yuan SF, Ding YY, Li R, Zheng XY, Shen B, Shen QR (2017) Rhizobacterium Bacillus amyloliquefaciens strain SQRT3-mediated induced systemic resistance controls bacterial wilt of tomato. Pedosphere 27(6):1135-1146

Li Y, Li Q, Hong Q, Lin Y, Mao W, Zhou S (2018) Reactive oxygen species triggering systemic programmed cell death process via elevation of nuclear calcium ion level in tomatoes resisting tobacco mosaic virus. Plant Sci 270:166-175

Liang Y, Cui S, Tang X, Zhang Y, Qiu D, Zeng H, Guo L, Yuan J, Yang X (2018) An asparagine-rich protein Nbnrp1 modulate Verticillium dahliae protein PevD1-induced cell death and disease resistance in Nicotiana benthamiana. Front Plant Sci 9:303. https://doi.org/10. 3389/fpls.2018.00303

Linlin L, Peng G, Hua J, Tianlai L (2016) Different proteomics of $\mathrm{Ca}^{2+}$ on SA-induced resistance to Botrytis cinerea in tomato. Hortic Plant $\mathrm{J}$ 2(3):154-162

Liu J-J, Williams H, Li XR, Schoettle AW, Sniezko RA, Murray M, Zamany A, Roke G, Chen H (2017) Profiling methyl jasmonateresponsive transcriptome for understanding induced systemic resistance in whitebark pine (Pinus albicaulis). Plant Mol Biol Doi 95: 359-374. https://doi.org/10.1007/s11103-017-0655-z

Lopez-Gresa MP, Lison P, Yenush L, Conejero V, Rodrigo I, Belles JM (2016) Salicylic acid is involved in the basal resistance of tomato plants to citrus exocortis viroid and tomato spotted wilt virus. PLoS
One 11(11):e0166938. https://doi.org/10.1371/journal.pone. 0166938

Lu F, Liang X, Lu H, Li Q, Chen Q, Zhang P, Li K, Liu G, Yan W, Song J, Duan C, Zhang L (2017) Overproduction of superoxide dismutase and catalase confers cassava resistance to Tetranychus cinnabarinus. Sci Rep 7:40179. https://doi.org/10.1038/srep40179

Lucas JA, García-Cristobal J, Bonilla A, Ramos B, Gutierrez-Manero J (2014) Beneficial rhizobacteria from rice rhizosphere confers high protection against biotic and abiotic stress inducing systemic resistance in rice seedlings. Plant Physiol Biochem 82:44-53

Luiz C, Rocha Neto AC, Di Piero RM (2015) Resistance to Xanthomonas gardneri in tomato leaves induced by polysaccharides from plant or microbial origin. J Plant Pathol 97(1):119-127. https://doi.org/10. 4454/JPP.V97I1.029

Ma Z, Ongena M, Hofte M (2017) The cyclic lipopeptide orfamide induces systemic resistance in rice to Cochliobolus miyabeanus but not to Magnaporthe oryzae. Plant Cell Rep 36:1731-1746. https:// doi.org/10.1007/s00299-017-2187-z

Malfanova N, Lugtenberg BJJ, Berg G (2013) Bacterial endophytes: who and where, and what are they doing there. In: deBruijn, F.J. (ed.), molecular microbial ecology of the rhizosphere. Wiley-Blackwell Hoboken, NJ, USA, p. 391-403

Martínez-Hidalgo P, García JM, Pozo MJ (2015) Induced systemic resistance against Botrytis cinerea by Micromonospora strains isolated from root nodules. Front Microbiol 6:922. https://doi.org/10.3389/ fmicb.2015.00922

Martınez-Medina A, Fernandez I, Lok GB, Pozo MJ, Pieterse CMJ, Van Wees SCM (2016) Shifting from priming of salicylic acid- to jasmonic acid-regulated defences by Trichoderma protects tomato against the root knot nematode Meloidogyne incognita. New Phytol 213:1363-1377. https://doi.org/10.1111/nph.14251

Mauch F, Mauch-Mani B, Boller T (1988) Antifungal hydrolases in pea tissue: II. Inhibition of fungal growth by combinations of chitinase and $\beta$-1.3-glucanase. Plant Physiol 88:936-942

Meco G, Bonifati V, Vanacore N, Fabrizio E (1994) Parkinsonism after chronic exposure to the fungicide maneb (manganese ethylene-bisdithiocarbamate). Scand J Work Environ Health 20:301-305

Miliute I, Buzaite O, Baniulis D, Stanys V (2015) Bacterial endophytes in agricultural crops and their role in stress tolerance: a review. Zemdirbyste-Agriculture 102(4):465-478

Mishra AK, Morang P, Deka M, Kumar NS, Kumar DBS (2014) Plant growth-promoting rhizobacterial strain-mediated induced systemic resistance in tea (Camellia sinensis (1.) o. kuntze) through defenserelated enzymes against brown root rot and charcoal stump rot. Appl Biochem Biotechnol 174:506-521. https://doi.org/10.1007/s12010014-1090-0

Molinari S, Fanelli E, Leonetti P (2014) Expression of tomato salicylic acid (SA)-responsive pathogenesis-related genes in Mi-1-mediated and SA-induced resistance to root-knot nematodes. Mol Plant Pathol 15(3):255-264

Nair A, Kolet SP, Thulasiram HV, Bhargava S (2014) Systemic jasmonic acid modulation in mycorrhizal tomato plants and its role in induced resistance against Alternaria alternata. Plant Biol pp. 1-7. https:// doi.org/10.1111/plb.12277

Nanda AK, Andrio E, Marino D, Pauly N, Dunand C (2010) Reactive oxygen species during plant-microorganism early interactions. J Integr Plant Biol 52:195-204

Nassar AMK, Adss IAA (2016) 2,4-Dichlorophenoxy acetic acid, abscisic acid, and hydrogen peroxide induced resistance-related components against potato early blight (Alternaria solani, Sorauer). Ann Agri Sci 61(1):15-23

Naveed M, Qureshi MA, Zahir ZA, Hussain MB, Sessitsch A, Mitter B (2015) L - Tryptophan-dependent biosynthesis of indole-3-acetic acid (IAA) improves plant growth and colonization of maize by Burkholderia phytofirmans PsJN. Ann Microbiol 65:1391-1389 
Nawrocka J, Małolepsza U, Szymczak K, Szczech M (2018) Involvement of metabolic components, volatile compounds, PR proteins, and mechanical strengthening in multilayer protection of cucumber plants against Rhizoctonia solani activated by Trichoderma atroviride TRS25. Protoplasma 255:359-373. https://doi.org/10. 1007/s00709-017-1157-1

Naznin HA, Kiyohara D, Kimura M, Miyazawa M, Shimizu M, Hyakumachi M (2014) Systemic resistance induced by volatile organic compounds emitted by plant growth-promoting fungi in Arabidopsis thaliana. PLoS One 9(1):e86882. https://doi.org/10. 1371/journal.pone.0086882

Nie P, Li X, Wang S, Guo J, Zhao H, Niu D (2017) Induced systemic resistance against Botrytis cinerea by Bacillus cereus AR156 through a JA/ET- and NPR1-dependent signaling pathway and activates PAMP-triggered immunity in arabidopsis. Front Plant Sci 8: 238. https://doi.org/10.3389/fpls.2017.00238

Niu D, Wang X, Wang Y, Song X, Wang J, Guo J, Zhao H (2016) Bacillus cereus AR156 activates PAMP-triggered immunity and induces a systemic acquired resistance through a NPR1-and SA-dependent signaling pathway. Biochem Biophys Res Commun 469:120-125

O'hanlon KA, Knorr K, Jorgensesn LN, Nicolaisen M, Boelt B (2012) Exploring the potential of symbiotic fungal endophytes in cereal disease suppression. Biol Control 63:69-78

Pieterse CMJ, Van der Does D, Zamioudis C, Leon-Reyes A, Van Wees SCM (2012) Hormonal modulation of plant immunity. Annu Rev Cell Dev Biol 28:489-521

Pieterse CMJ, Zamioudis CBRL, Weller DM, Van Wees SCM, Bakker PAHM (2014) Induced systemic resistance by beneficial microbes. Annu Rev Phytopathol 52:347-375

Planchamp C, Glauser G, Mauch-Mani B (2015) Root inoculation with Pseudomonas putida KT2440 induces transcriptional and metabolic changes and systemic resistance in maize plants. Front Plant Sci 5(719):1-10. https://doi.org/10.3389/fpls.2014.00719

Raaijmakers JM, Mazzola M (2016) Soil immune responses. Sci 352: $1392-1393$

Rais A, Jabeen Z, Shair F, Hafeez FY, Hassan MN (2017) Bacillus spp., a bio-control agent enhances the activity of antioxidant defense enzymes in rice against Pyricularia oryzae. PLoS One 12(11): e0187412. https://doi.org/10.1371/journal.pone.0187412

Raut SA, Borkar SG (2014) PR-proteins accumulation in tomato plant due to application of resistance inducing chemicals during period of induced resistance against Alternaria leaf blight. Sci Int J 2:72-75

Raza W, Yousaf S, Rajer FU (2016) Plant growth promoting activity of volatile organic compounds produced by biocontrol strains. Sci Lett 4:40-43

Salas-Marina MA, Isordia-Jasso MI, Islas-Osuna MA, Delgado-Sánchez P, Jiménez-Bremont JF, Rodríguez-Kessler M, Rosales-Saavedra MT, Herrera-Estrella A, Casas-Flores S (2015) The Epl1 and Sm1 proteins from Trichoderma atroviride and Trichoderma virens differentially modulate systemic disease resistance against different life style pathogens in Solanum lycopersicum. Front Plant Sci 6(77):113

Santhanam R, Luu VT, Weinhold A, Goldberg J, Oh Y, Baldwin IT (2015) Native root-associated bacteria rescue a plant from a sudden-wilt disease that emerged during continuous cropping. PNAS pp. 1-8. https://doi.org/10.1073/pnas.1505765112

Saravanakumar K, Fan L, Fu K, Yu C, Wang M, Xia H, Sun J, Li Y, Chen J (2016) Cellulase from Trichoderma harzianum interacts with roots and triggers induced systemic resistance to foliar disease in maize. Sci Rep 6:35543. https://doi.org/10.1038/srep35543

Sharma CK, Vishnoi VK, Dubey RC, Maheshwari DK (2018) A twin rhizospheric bacterial consortium induces systemic resistance to a phytopathogen Macrophomina phaseolina in mung bean. Rhizosphere 5:71-75
Shine MB, Xiao X, Kachroo P, Kachroo A (2018) Signaling mechanisms underlying systemic acquired resistance to microbial pathogens. Plant Sci :https://doi.org/10.1016/j.plantsci.2018.01.001

Singh UB, Malviya D, Wasiullah Singh S, Pradhan JK, Singh BP, Roy M, Imram M, Pathak N, Baisyal BM, Rai JP, Sarma BK, Singh RK, Sharma PK, Kaur SD, Manna MC, Sharma SK, Sharma AK (2016) Bio-protective microbial agents from rhizosphere eco-systems trigger plant defense responses provide protection against sheath blight disease in rice (Oryza sativa L.). Microbiol Res 192:300-312

Song GC, Ryu CM (2013) Two volatile organic compounds trigger plant self-defense against a bacterial pathogen and a sucking insect in cucumber under open field conditions. Int J Mol Sci 14:9803-9819

Song Y, Chen D, Lu K, Sun Z, Zeng R (2015) Enhanced tomato disease resistance primed by arbuscular mycorrhizal fungus. Front Plant Sci 6:786. https://doi.org/10.3389/fpls.2015.00786

Spence C, Alff E, Johnson C, Ramos C, Donofrio N, Sundaresan V, Bais $\mathrm{H}$ (2014) Natural rice rhizospheric microbes suppress rice blast infections. BMC Plant Biol 14:130

Srikantaramas S, Yamazaki M, Saito K (2008) Mechanisms of resistance to self-produced toxic secondary metabolites in plants. Phytochem Rev 7:467-477

Stamler RA, Holguin O, Dungan B, Schaub T, Sanogo S, Goldberg N, Randall JJ (2015) BABA and Phytophthora nicotianae induce resistance to Phytophthora capsici in Chile pepper (Capsicum annuum). PLoS One 10(5):e0128327. https://doi.org/10.1371/ journal.pone. 0128327

Stangarlin JR, Kuhn OJ, Toledo MV, Portz RL, Schwan-Estrada KRF, Pascholati SF (2011) A defesa vegetal contra fitopatógenos. Sci Agrar Paranaen 10(1):18-46

Su F, Villaume S, Rabenoelina F, Crouzet J, Clément C, Vaillant-Gaveau N, Dhondt-Cordelier S (2017a) Different Arabidopsis thaliana photosynthetic and defense responses to hemibiotrophic pathogen induced by local or distal inoculation of Burkholderia phytofirmans. Photosynth Res 134(2):201-214. https://doi.org/10.1007/s11120017-0435-2

Su P, Tan X, Li C, Zhang D, Cheng J, Zhang S, Zhou X, Yan Q, Peng J, Zhang Z, Liu Y, Lu X (2017b) Photosynthetic bacterium Rhodopseudomonas palustris GJ-22 induces systemic resistance against viruses. Microbial Biotechnol 10:612-624

Tada Y, Spoel SH, Pajerowska-Mukhtar K, Mou Z, Song J, Wang C, Zuo J, Dong X (2008) Plant immunity requires conformational charges of NPR1 via S-nitrosylation and thioredoxins. Science 321:952956. https://doi.org/10.1126/science.1156970

Tahir HAS, Gu Q, Wu H, Raza W, Safdar A, Huang Z, Rajer FU, Gao X (2017) Effect of volatile compounds produced by Ralstonia solanacearum on plant growth promoting and systemic resistance inducing potential of Bacillus volatiles. BMC Plant Biol 17:133. https://doi.org/10.1186/s12870-017-1083-6

Tonelli ML, Fabra A (2014) The biocontrol agent Bacillus sp. CHEP5 primes the defense response against Cercospora sojina. World J Microbiol Biotechnol pp.1-7. Doi: https://doi.org/10.1007/s11274014-1675-3, 30, 2503, 2509

Tonelli ML, Magallanes-Noguera C, Fabra A (2017) Symbiotic performance and induction of systemic resistance against Cercospora sojina in soybean plants co-inoculated with Bacillus sp. CHEP5 and Bradyrhizobium japonicum E109. Arch Microbiol 199:12831291. https://doi.org/10.1007/s00203-017-1401-2

Toyota M, Spencer D, Sawai-Toyota S, Jiaqi W, Zhang T, Koo AJ, Howe GA, Gilroy S (2018) Glutamate triggers long-distance, calciumbased plant defense signaling. Sci 361:1112-1115

Vacheron J, Renoud S, Muller D, Babalola OO, Prigent-Combaret C (2015) Alleviation of abiotic and biotic stresses in plants by Azospirillum. In: Cassain FD et al., (eds), Handbook for Azospirillum, Technical issues and protocol, Springer international publishing Switzerland, pp. 333-365 
Van Lelyveld LJ, Brodrick HT (1975) Enzymic responses of avocado leaves to Phytophthora root rot. Agroplantae 7:13-16

Vanitha SC, Niranjana SR, Umesha S (2009) Role of phenylalanine ammonia lyase and polyphenol oxidase in host resistance to bacterial wilt of tomato. J Phytopathol 157:552-557

Velivelli SLS, Lojan P, Cranenbrouck S, de Boulois HD, Suarez JP, Declerck S, Franco J, Prestwich BD (2015) The induction of ethylene response factor 3 (ERF3) in potato as a result of co-inoculation with Pseudomonas sp. R41805 and Rhizophagus irregularis MUCL 41833 - a possible role in plant defense. Plant Signal Behav 10(2): e988076

Vinale F, Sivasithamparam K, Ghisalberti EL, Marra R, Woo SL, Lorito M (2008) Trichoderma-plant-pathogen interactions. Soil Biol Biochem 40:1-10

Vitti A, La Monaca E, Sofo A, Scopa A, Cuypers A, Nuzzaci M (2015) Beneficial effects of Trichoderma harzianum T-22 in tomato seedlings infected by cucumber mosaic virus (CMV). BioControl 60: 135-147. https://doi.org/10.1007/s10526-014-9626-3

Walley JW, Shen Z, McReynolds MR, Schmelz EA, Briggs SP (2018) Fungal-induced protein hyperacetylation in maize identified by acetylome profiling. PNAS pp. $1-6$. www.pnas.org/cgi/doi/10. 1073/pnas.1717519115, 115, 215

Wang N, Liu M, Guo L, Yang X, Qiu D (2016) A novel protein elicitor (PeBA1) from Bacillus amyloliquefaciens NC6 induces systemic resistance in tobacco. Int J Biol Sci 12(6):757-767. https://doi.org/ $10.7150 /$ ijbs. 14333

Wei Y, Xu M, Wu H, Tu S, Pan L, Tu K (2016) Defense response of cherry tomato at different maturity stages to combined treatment of hot air and Cryptococcus laurentii. Postharvest Biol Technol 117: 177-186

Xu QT, Fan HY, Jiang Z, Zhou ZQ, Yang L, Mei FZ, Qu LH (2013) Cell wall degradation and the dynamic changes of $\mathrm{Ca}^{2+}$ and related enzymes in the developing aerenchyma of wheat (Triticum aestivum L.) under waterlogging. Acta Biol Hung 64:328-340

Yan Y, Tang L, Hu J, Wang J, Adelakun TA, Yang D, Di Y, Zhang Y, Hao X (2018) Munronin O, a potential activator for plant resistance. Pestic Biochem Physiol 146:13-18

Yoodee S, Kobayashi Y, Songnuan W, Boonchird C, Thitamadee S, Kobayashi I, Narangajavana J (2018) Phytohormone priming elevates the accumulation of defense-related gene transcripts and enhances bacterial blight disease resistance in cassava. Plant Physiol Biochem 122:65-77

Yu C, Fan L, Gao J, Wang M, Wu Q, Tang J, Li Y, Chen J (2015) The platelet-activating factor acetylhydrolase gene derived from Trichoderma harzianum induces maize resistance to Curvularia lunata through the jasmonic acid signaling pathway. J Environ Sci Health 50(10):708-717. https://doi.org/10.1080/03601234.2015. 1048104

Zamioudis C, Pieterse CMJ (2012) Modulation of host immunity by beneficial microbes. Mol Plant-Microbe Interact 25:139-150

Zeng W, He SY (2010) A prominent role of the flagellin receptor flagellin-sensing2 in mediating stomatal response to Pseudomonas syringae pv tomato DC3000 in Arabidopsis. Plant Physiol 153(3): 1188-1198

Zhang Y, Yan X, Guo H, Zhao F, Huang L (2018) A novel protein elicitor BAR11 from Saccharothrix yanglingensis Hhs.015 improves plant resistance to pathogens and interacts with catalases as targets. Front Microbiol 9:700. https://doi.org/10.3389/fmicb.2018.00700

Zheng X-Y, Zhou M, Yoo H, Pruneda-Paz JL, Spivey NW, Kay SA, Dong X (2015) Spatial and temporal regulation of biosynthesis of the plant immune signal salicylic acid. PNAS 112(30):9166-9173

Zhu F, Xi D-H, Yuan S, Xu F, Zhang D-W, Lin H-H (2014) Salicylic acid and jasmonic acid are essential for systemic resistance against tobacco mosaic virus in Nicotiana benthamiana. Mol Plant Microbe Interact 27(6):567-577. https://doi.org/10.1094/MPMI-11-13-0349-R 